\title{
Çalkantılı Bir Dönemin Kültür Sahnesi Olarak Dârüllelhan: Geleneğin Yeniden Tanımlanması
}

\section{Dârülelhan as the Cultural Stage of Tumultuous Times: Redefining of Tradition}

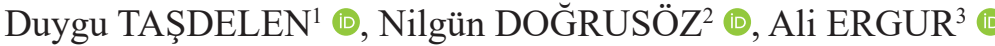

'Sorumlu yazar/Corresponding author: Duygu Taşdelen (Dr.),

İstanbul Teknik Üniversitesi, Lisansüstü Eğitim Enstitüsü, Müzikoloji ve Müzik Teorisi Programı, Istanbul, Türkiye

E-posta: duygutasdelen@anadolu.edu.tr ORCID: 0000-0001-5296-2701

${ }^{2}$ Nilgün Doğrusöz Prof. Dr.), İstanbul Teknik Üniversitesi, Türk Musikisi Devlet Konservatuarı, Müzik Teorisi Bölümü, İstanbul, Türkiye

E-posta: dogrusozn@itu.edu.tr ORCID: 0000-0003-4818-4075

${ }^{3}$ Ali Ergur (Prof. Dr.),

Galatasaray Üniversitesi, Fen-Edebiyat Fakültesi, Sosyoloji Bölümü, İstanbul, Türkiye

E-posta: aergur@gsu.edu.tr

ORCID: 0000-0001-8510-4287

Başvuru/Submitted: 16.03 .2021

Revizyon Talebi/Revision Requested: 20.08.2021

Son Revizyon/Last Revision Received: 28.08.2021

Kabul/Accepted: 14.10.2021

Online Yayın/Published Online: 08.12.2021

Atıf/Citation: Tasdelen, Duygu. Dogrusoz, Nilgun. ve Ergur, Ali. "Çalkantılı Bir Dönemin Kültür Sahnesi Olarak Dârülelhan: Geleneğin Yeniden Tanımlanması." Türkiyat MecmuasıJournal of Turkology 31, 2 (2021): 819-849. https://doi.org/10.26650/iuturkiyat.898297

\section{öz}

Dârülelhan, hem Osmanlı Devleti'nin son dönemlerinin hem de yeni kurulmuş olan Türkiye Cumhuriyeti'nin müzik alanındaki okulu olarak faaliyet göstermiştir. 18. yüzyıl sonlarından itibaren modernleşme etkisinde olan Osmanlı Devleti'nde askerî ve toplumsal yaşamda olduğu gibi müziğin kültürel üretim sahasında da değişmeler yaşanmıştır. Türk müziğinin özellikle aktarım, nazariyat ve icra geleneğinde dönüşümlerin yaşandığı bu süreçte, değişmenin modern eğitim kurumları eliyle yeniden inşa edilmesi ve Türk müziği eğitiminin kurumsallaşması ihtiyacı ve fikri gündeme gelmeye başlamıştır. 1916 yılında eğitim faaliyetlerine başlayan, 1923 yılında yeniden yapılandırılan Dârülelhan'a; Türk müziğini ve dönemin müzikal beğenisini şekillendirme hususunda önemli bir misyon yüklenmiştir. Bu çalışmanın amacı, -konu gereği genel bir çerçeve çizilmiş olmakla beraber kurum tarihini anlatmaktan ziyade- Osmanlı Devleti'nin son dönemleri ve Cumhuriyet döneminin ilk yıllarında Türk müziğinin aktarım ve icra geleneklerinin Dârülelhan aracılığıyla nasıl şekillendirilmeye çalışıldığını ele almaktır. Çalışmada Dârülelhan ile gerçekleştirilmeye çalışılan yenilikler ve amaçlar, kurumun yönetmelikleri, mevzuatları ve dönemin yayınları incelenerek saptanmış; belirlenen amaçların uygulamaları dönem şartları içerisinde değerlendirilmiştir. Bunların yanı sıra makalede, gerçekleştirmeye çalışılan yeniliklerin, müzik çevrelerinde ne şekilde karşılık bulduğu incelenmiştir. Ulaşılan yeni belge ve bilgilerle de kurumun tarihsel süreciyle ilgili yapılmış olan öncül çalışmalara ilaveler yapılmıştır.

Anahtar kelimeler: Dârülelhan, gelenek, kurumsallaşma, Türk müziğinde kurumsallaşma çabası, Türk müziği eğitimi tarihi

\section{ABSTRACT}

Dârülelhan served as the national school of music both during the late Ottoman era and the newly founded Republic of Turkey. During this period, there were considerable changes in the cultural production of music, similar to those in the military and social life of the Ottoman State that was undergoing modernization -and the rationalizing its effect- as early as the late 18th Century. During this process, when the fields of teaching, theory, and performance of Turkish music were rapidly transforming, a rationalization and an underlying idea for constructive change was put into place. It was ultimately anticipated to arrive via modern educational institutions, and thus the institutionalization of Turkish music gathered momentum. Dârülelhan, which became operational in 1916 
and continued offering its training even after a restriction of its functions in 1923, was charged with an important mission in shaping both traditional Turkish music and the musical taste of the time. This study -although the topic necessitates a general outline- does not deal with the history of the institution itself but rather focuses on Turkish music's teaching and performance traditions that changed during the late Ottoman and early republican eras at the hands of Dârülelhan. The paper examines the institution's directives, legislation, and publications during the said period and discusses the time's socio-cultural implementations by considering news articles and interviews in periodicals as well as other archival documents. Additionally, it studies their reception within prominent musical circles, making additions to predicate studies on the institution's history by analyzing newly discovered documents and other supplementary information.

Keywords: Dârülelhan, tradition, institutionalization, institutionalization efforts in Turkish music, history of Turkish musical education

\section{EXTENDED ABSTRACT}

Westernization movements that began during the Tulip Age (1718-1730) in the Ottoman State were observed in the periphery of the palace, initially taking roots in the military and subsequently affecting social, cultural, educational, musical, and virtually all cultural spheres. Its impact on Turkish music can be seen in the transformed performance styles and modernized teaching traditions. These factors, along with standardization efforts, have brought about the need for a school wherein Turkish musical education would be sustained, and the music would be institutionalized.

Prior to Dârülelhan; the teachings of Turkish music occurred in institutions and venues such as the Mevlevîhane, Mehterhane, Enderun, Muzıka-yı Hümâyûn; and specialized societies such as Dârü'l-Musiki-yi Osmanî, Dârü'l Feyz-i Musiki, Dârü 't-Talim-i Musiki, Gülşen-i Musiki, and Şark Musikisi Cemiyeti (Western Music Society). As well as grand mansions belonging to music lovers and cult convents have served a similar purpose.

The music department of Dârülbedayi -originally established for theater in 1914- is important as it is regarded as a stepping-stone to the establishments of Dârülelhan. However, the Turkish music department at the institution was shut down in 1916 due to the economic impacts of World War I.

Dârülelhan was subsequently established in 1916 to address the need for the institutionalizing and representing Turkish music by offering quality education in the field. In its initial configuration, it was planned as an institution with two campuses, offering separate classes for men and women. The men's campus was closed due to the economic effects of WWI and classes at the institute continued solely in the women's branch.

Dârülelhan was restructured with Eastern and Western music departments and reopened in 1923 during the republic period, during which it operated as a far more efficient institution compared to its past form, producing concerts, compilations, and publications as well as offering numerous classes. However, prolonged discussions on Eastern and Western music, widely covered by the media in 1926, led to the idea of entirely eliminating Turkish music from official institutions.

At the first conservatory of the Ottoman State and the Republic of Turkey, Dârülelhan was charged with the important mission of reconstructing the musical taste and production 
of its day during both eras of its activity. A review of interviews during its establishment, and articles stipulating the institution's purposes in the legislation, clearly show that the institution was perceived as the government agency that would shape the anticipated change in the field of music. Established to meet Turkish music's need for institutionalization, Dârülelhan's fundamental purposes included the scientific application of Turkish music along with registering and reviving old works and compositions that were a part of its inception in 1916, when the ordinance regarding the institution was first published. Education, both through notation and makams (melody types) in realizing these purposes, was gravely emphasized. The fundamental goals of the institution are a reflection of the positivist and rationalist thought on music that were prevalent during the period. There was an attempt to convert the teachings of Turkish music, which occurred primarily through meşk -an element of oral culture- that followed the footsteps of its precursors into written culture. Although notation -an element of Western culture- was used, edvars, which were the most significant source in teaching Turkish music theory, were reference points in scientific discipline. Another aim was to propel change in various fields of Turkish music tradition, which began with the westernization process in the Ottoman State through Dârülelhan's education and arts activities as well as the efforts of the alumni. However, the institution was unable to operate as planned during its inception due to financial troubles and the effects of the World War.

Beginning in 1923, Dârülelhan was once again expected to operate as a "modern" institution much like its counterparts in Europe. This second period was far more productive than the first, both in the sense of works carried out at the institution and its artistic activities, along with a better convergence of planning and implementation. The institution organized concerts that exemplified the use of notation, and the publication activities along with it illustrated the changes that were implemented in Turkish music's performance and teaching traditions. The surviving art forms carried an unprecedented concerted purpose of creating literature through a register of Turkish music and the first systematic efforts that took place in the field.

Dârülelhan, which operated non-continuously due to and under two different structures between 1916 and 1926 due to a consequence of its times, made significant contributions to the transition of written culture and developments in the creation of literature, registering and recording compositions, and transitioning education through notation in a time period that was too short to realize the missions it had assumed. 


\section{Giriş}

Williams'a göre gelenek kelimesinin İngilizce karşılığg 'tradition' “İngilizceye 14. yüzyılda eski Fransızca ‘tradicion' dan, bu sözcük de Fransızcaya, Latince 'traditionem' ile geçmiştir. “Traditionem” kökü ‘tredere' sözcüğünden gelmektedir. 'Tredere'nin Latincede dört farklı anlamı bulunmaktadır. Bunlar; verme, teslim etme, bilgiyi aktarma, bir öğretiyi aşılama, teslim olma veya ihanettir. 17. yüzyıldan itibaren "bilgiyi aktarma" ve "bir öğretiyi aşılama" anlamları yaygınlaşıp, ihanet ve teslim olma anlamlarını gölgede bırakmıştır. ${ }^{1}$ Farklı kaynaklardaki gelenek tanımları ${ }^{2}$ incelendiğinde, kavramın tanımlarının farklılıklar içerdiği görülmektedir. Tanımlar incelendiğinde, bunların geleneğin farklı özelliklerini vurguladıkları gözlemlense de; ortak olarak zikredilen sadece iki olgu olması dikkat çekicidir. Bu iki olgu 'intikal' ve 'geçmişe aitlik’tir. Ancak “bu konuda kesin bir tanım arayışına girmek yerine, farklı kullanımlarından yararlanmak, kavramın ayrı anlamları üzerinde düşünmek daha anlamlıdır. Böylece gelenek, açık bir kavram haline getirilebilir."

Gelenekle ilgili tanımlara bakıldığında geçmişten bir olgunun/şeyin hatırlanmaya ve yeniden yaşanmaya devam edecek biçimde şimdiki zamanda tutuluyor ve sürdürülüyor olduğu fark edilmektedir. Bu sürdürülebilme durumunu gerçekleştirebilmek için de gelenekler; geçmişle kurduğu bağı korumak suretiyle ekonomik, kültürel, tarihî ve siyasî etkiler ile esneyebilmekte, kırılabilmekte ve değişebilmektedir. Türk Müziği alanına bakıldığında ise 18. yüzyılın başlarından itibaren dönemin hızlı değişen toplumsal yapısı ile birlikte bir dönüşümün gerçekleştiği görülmektedir. ${ }^{4}$

Literatüre bakıldığında, Dârülelhan kurumu ile ilgili olarak pek çok çalışma yapıldığı görülmektedir.

Önemli öncül çalışmalardan biri Kubilay Kolukırık'ın Türk Müzik Tarihinde Dârü'l- Elhan ve Dârü'l-Elhan Mecmuası adlı kitabıdır. Bu kitapta, Osmanlı Devleti'nde Dârülelhan'dan önce müzik eğitimi veren kurumlar incelenmiş, Dârülelhan'ın kuruluşu ve tarihsel süreci üzerinde durulmuş ve Dârülelhan Mecmuası'nda yayımlanan Osmanlı Türkçesi ile yazılmış makalelerin günümüz Türkçesine çevirisi okuyucuya sunulmuştur.

Erhan Özden tarafından kaleme alınan Osmanlı Devleti'nin Konservatuvarı Dârülelhan (Arşiv Belgeleriyle), Ahmet Kara tarafından hazırlanan Bir Müzik Eğitim Kurumu Olarak

1 Raymond Williams, Anahtar Sözcükler, çev. Savaş Kılıç (İstanbul: Sena Ofset, 2012), 386.

2 Tanımlar ve detaylı bilgi için bk. Ivan Frolov, Felsefe Sözlüğü, çev. Aziz Çalışlar (İstanbul: Cem Yayınevi, 1991). Ahmet Cevizci, Felsefe Sözlüğ̈̈ (İstanbul: Paradigma Yayınc1lık, 2005). Sibel Özbudun, “Gelenek”, Antropoloji Sözlüğ̈̈, haz. Kudret Emiroğlu ve Suavi Aydın (Ankara: Bilim ve Sanat Yayınları, 2003). Williams, Anahtar Sözcükler, 386. Edward Shils, Tradition (Chicago: The University of Chicago Press, 1981). Eric Hobsbawm ve Terence Ranger, Geleneğin İcadl, çev. Mehmet Murat Şahin (İstanbul: Agora Kitaplığı, 2006).

3 Gül Özsan, "Kültür ve Gelenek", Kültür Sosyolojisi içinde, (Eskişehir: Anadolu Üniversitesi Basımevi, 2015), 86.

4 Ayr. bilgi için bk. Ali Ergur ve Yiğit Aydın, "Patterns of Modernization in Turkish Music As Indicators of Changing Society”, Musicae Scientiae Özel Sayı (2005-2006), 89-105. Ali Ergur, "Türkiye’de Müziğin Modernleşme Süreci: Tampere Düzene Geçişin Yerel ve Evrensel Boyutları", Müzikli Aklın Defteri içinde, (İstanbul: Pan Yayınc1lı, 2009), 169-182. 
Darülelhan ve Mecmuası başlıklı yüksek lisans tezi ve Kuruluşunun 100. Yılında Darülelhan kitabı da yine kurumun tarihsel süreci üzerinde duran çalışmalardandır. Erhan Özden tarafından kaleme alınan Osmanlı'da Musiki Okulları başlıklı makale Dârülbedayi' den başlayarak Osmanlı Devleti'ndeki müzik okulları hakkında genel bilgiler içermektedir.

Editörlüğünü Gülçin Yahya Kaçar'ın yaptığg Kuruluşunun Yüzüncü Yılında Darü'l- Elhan'a Armağan kitabında kurum, kurumda çalışan kişiler ya da yapılan faaliyetler ve Türk müziği eğitimi hakkında çeşitli yazarlar tarafından kaleme alınan çalışmalar bulunmaktadır. Bu çalışmaların yanı sıra Konservatoryum dergisinin beşinci cildinin birinci sayında Dârülelhan ile ile ilgili üç makale yayınlanmıştır.

Literatür taramasından, Dârülelhan kurumu üzerine yapılan çalışmaların içerik olarak arşiv belgeleri üzerinden kurumun tarihsel sürecinin çerçevesini çizmek; çıkardığı mecmuanın çevirisini yapmak gibi konular hakkında olduğu anlaşılmaktadır.

Bu makalede ise, Osmanlı Devleti'nin son dönemleri ve Cumhuriyet döneminin ilk yıllarında Türk müziğinin aktarım ve icra geleneklerinin Dârülelhan aracılığıyla nasıl şekillendirilmeye çalışıldığı ele alınmaktadır. Kurumun yönetmelikleri, mevzuatları ve dönemin yayınlarından yola çıkarak Dârülelhan kurumu ile Türk müziğinin aktarımı ve icrası alanlarında gerçekleştirilmeye çalışılan değişmeler incelenmiştir. Dönemin müziğinin şekillendirici resmî müzik okulu olan Dârülelhan ile gerçekleştirilmek istenen bu değişmenin dönem şartları içerisinde ne kadarının sağlandığı/sağlanamadığı ve bunun müzik çevrelerinde ne şekilde karşılık bulduğu değerlendirilmiştir.

\section{Dârülelhan Öncesi Türk Müziği Eğitimine Bakış}

Dârülelhan'ın öncesinde Mevlevîhane, Mehterhane, Enderun, Muzıka-yı Hümâyûn gibi kurum ve mekanlarda Türk müziğinin aktarımı ve eğitimi sürdürülmüş; bunların yanı sıra Dârü'l-Musiki-yi Osmanî, Dârü'l Feyz-i Musiki, Dârü’t-Talim-i Musiki, Gülşen-i Musiki, Şark Musikisi Cemiyeti gibi cemiyetler, musikişinas konakları, çeşitli tarikat dergâhları da benzer işlevi görmüştür. ${ }^{5}$

1914 yılında tiyatro alanında kurulan Dârülbedayi’nin, musiki bölümü, Türk müziğinin kurumsallaşması ihtiyacına karşılık olarak, Dârülelhan'ın hazırlayıcısı mahiyetinde görülmesi bakımından önem taşımaktadır. ${ }^{6}$ Dârülbedayi’nin musiki kısmının kuruluş aşamasında, Şark ve Garp musikisi şubelerinin açılması planlanmış, bölümün başkanlığına, 'Dârülbedayii Osmanî kısmı musiki reisi'” ünvanıyla Ali Rifat Çağatay (1867-1935) getirilmiştir. Ali Rifat

5 Ayr. bilgi için bk. Kubilay Kolukırık, Türk Müzik Tarihinde Dârü'l-Elhan ve Dârü'l-Elhan Mecmuası (Ankara: Barış Kitap, 2015).

Hikmet Toker ve Erhan Özden, “Osmanlı Devletinde Müzik Eğitimi Veren Önemli Kurumlar”, Rast Müzikoloji Dergisi 1/2 (2013), 107-128.

6 Dârülbedayi’nin Türk musiki kısmının kurulduğu yıl olan 1914 yılından, Dârülelhan'ın Türk müziği şubesinin kapatıldığı yıl olan 1926 yılına kadar geçen sürede kurumların tarihinin ve siyasal, kültürel olayların karşılaştırmalı kronolojisi için bk. (Tablo 1).

7 Refik Ahmet Sevengil, Yakın Çağlarda Türk Tiyatrosu (İstanbul: Kanaat Kütüphanesi, 1934), 91. 
Çağatay'ın, Dârülbedayi'nin kuruluş aşamasında, kurumun müzik alanındaki misyonu ile ilgili soruya verdiği cevaptan Dârülbedayi'nin musiki şubesinin amacını, repertuvarı korumak ya da aktarmaktan ziyade 'Osmanlı' dönemi müziğinin makamlarını korumak şartıyla opera ve operetler bestelemek olarak tasavvur ettiği anlaşılmaktadır.

Çağatay, şubelerin amaçları ve eğitim kadroları ile ilgili bilgi vermektedir.

"Tiyatro musikisi denilince derhal tenoru, baritonu, sopranosu velhasıl armoni için lâzım olan eşkâli muhtevi bir heyeti musikiye gelir. Ve böyle bir heyeti ortaya çıkarmak için de konservatuvara lüzum görülür. Şehremanetinin teşebbüsü bu ümniyenin [isteğin] husulüne [olmasına] matuf olduğu [yöneldiği] cihetle şehrimizin en maruf [ünlü] ve en iktidarlı esatizesi olan Zatî, Zeki, Cemil Beyefendilerle mösyö Radagilo, Selülli, Forlâti, Adolyo gibi zevattan güzide bir heyeti müessese teşkil edilmiş ve ankarip [yakın zamanda] başlanılacak olan müzakerata zemin olacak raporların ihzarına başlanmıştır. İstihbar buyurduğunuz alaturka musiki büsbütün başkadır. Musikiî Osmanî hakkındaki fikir; klâsik musikimizin vikayesi [korumas1] ile beraber bunun ileride tiyatroya da yarayabilecek bir şekle ifrağı esbabını istihsal etmekten ibarettir. Bu cihet için de Rauf Yekta Beyefendi, Zekaizade Ahmed Efendi, Cemil, Sadettin, Suphi ve Baha Beyefendiler ve Leon Hancıyan Efendi gibi muharrir ve muallimlerden mürekkep bir heyeti fenniye teşkil edilmiş ve içtimaata mübaşeret [başlamak] edilmek üzere cümlesi davet olunmuşlardır."

Bu açıklamalardan anlaşılacağı üzere, Çağatay’a göre her iki şubenin de tiyatro için müzik bestelemek misyonuna sahip olduğu açıktır. Bu iki şubenin kurulları 22 Temmuz ve 6 Eylül 1914 tarihleri arasında altı kez biraraya gelip; ders planları, öğrenci alımı, öğretim kadrosu gibi konuların konuşulduğu toplantılar düzenlemişlerdir. ${ }^{9}$

Şark ve Garp musikisi şubelerinin ikisinin de reisi olan Ali Rifat Çağatay’a göre repertuvarı aktarmak musiki cemiyetlerinin ve meşkhanenin vazifesidir. Ancak 1915 yılında yapılan Dârülbedayi’nin yönetim kurulu toplantısında bölümün görevleri ‘Doğu' müziğini kaybolmaktan ve bozulmaktan korumak; eski Türk müziği eserlerini o zamanlar çalındığı haliyle notaya alıp eserlerin unutulmasını önlemek; musiki zevkini yaymak olarak belirlenmiştir. Bu toplantıyla, Şark ve Garp şubeleriyle eğitim vermesi planlanan Dârülbedayi'de, sadece Şark müziği şubesinin eğitim vermesi kararlaştırılmıştır. Çağatay'ın tasavvurları ile alınan kararların birbiriyle örtüşmediği, en temelde fikir ayrılıklıklarının yaşandığı açıktır. Kurul, Çağatay’ın musiki cemiyetlerine atfettiği görevi, şubenin asıl amaçlarından biri olarak belirlemiş; bununla birlikte şubeye, hayali kurulan makamsal opera ve operetlerle ilgili herhangi bir misyon verilmemiştir. Yayılması istenen müzik zevki ile ilgili bir veri verilmese de, kurumdaki müzik anlayışının toplumun müzikal beğenisini şekillendirmesi hedeflenmektedir. Bu kararlardan bir süre önce Ali Rifat Çağatay görevinden çekilmiş; kendisinin yerine Şehremini muavini Bekir Bey "Dârülbedayi musiki kısmı muamelâtını tedvire memur"10 olarak getirilmiş, bölümle ilgili

8 Osman Nuri Ergin, Türkiye Maarif Tarihi, (İstanbul: Osmanbey Matbaası, 1977), 1534.

9 Toplantılarla ilgili detaylı bilgi için bk. Nilgün Doğrusöz ve Ali Ergur, "Çatışmalar ve Dönüşümler Çağında Bir Bileşimci: Ali Rifat Çağatay", Musikinin Asrî Prensi Ali Rifat Çağatay içinde, (İstanbul: Gece Kitaplı̆̆ı, 2017), 51-55.

10 Sevengil, Yakın Çağlarda Türk Tiyatrosu, 99. 
kararlar içinde müzikle ilgili kimse bulunmayan bir kurul tarafından verilmiştir. ${ }^{11}$

Dârülbedayi'nin ilk temsili, 20 Ocak 1916 tarihinde Emile Fabre'ın La Maison D'Argile oyununun, Hüseyin Suat Bey (1867-1942) tarafindan adapte edilen Çürük Temel piyesidir. Piyesin ardından Rast makamından eserlerin seslendirildiği bir konser verilir. Konser, 'Rast makamından bazı asar-1 eslâf’ başlığıyla program kitapçığında yer almıştır. Dârülbedayi muallimlerinden Cemil Bey'in (1873-1916) taksimiyle başlayan konserde; Benli Hasan Ağa'nın Rast Peşrevi, Dede Efendi'nin Rast Kâr-1 Nev'i, Hafız Post'un Rast Yürük Semaisi, Hacı Arif Bey'in Şarkısı, Benli Hasan Ağa'nın Saz Semaisi seslendirilmiştir. Konserde çalınan eserler, klasik fasıl sıralamasına benzerlik göstermekle birlikte; dönemin popüler türü olan şarkı, büyük soluklu usullerle yaratılmış 1 . ve 2. Beste türünün yerini almış, fasıl kısaltılmış ve ağır semaî türünde eser çalınmamıştır. Klasik fasıl, -muhtemelen dinlenilebilirliği yükseltmek adınadönemin müzikal beğeni anlayışına uyarlanmış ve fasılın genel yapısı korunmak suretiyle döneme adapte edilmiştir.

$\mathrm{Bu}$ konser için "musiki heyetine birer kat istanbulin denilen elbiseden"12 satın alınmıştır. İstanbulin, Tanzimat sonrası memurlara zorunlu tutulan, 'yavaş yavaş batılılaşmış bir bürokrasinin görünürdeki işaretleri'ni sembolize eden ve 'Tanzimatçı Türk'ün tercih ettiği bir giysidir. ${ }^{13} \mathrm{Bu}$ konser için seçilen repertuvar ile birlikte musiki heyetinin görünümü de dönemin batılılaşmakta olan ruhunu yansitacak şekilde belirlenmiştir.

Dârülbedayi süreç içinde, bir eğitim kurumundan çok temsilleri ile faaliyet gösteren bir kurum olmuştur. Dârülbedayi' deki müzik eğitiminin içeriği ile ilgili olarak da, yoğun konser programlarının uygulandığı göz önünde bulundurularak, icraya yönelik bir eğitim uygulandığı söylenebilir.

I. Dünya Savaşı'nın etkisiyle maddi olarak sıkıntı yaşanan kurumda, “ilk iş esasen üvey evlat olan musiki kısmı" "14 yönetim kurulu kararınca 14 Mart 1916 tarihinde kapatılmıştır.

\section{Türk Müziği’nin Kurumsallaşma İhtiyacı}

Sosyal bilimlerde toplumsal kurum terimi, "kişilerin temel sosyal gereksinmelerini karşılama amacıyla belirli, onaylanmış ve birleştirilmiş tarzlarda oynadıkları oldukça sürekli sosyal kalıp, rol ve ilişki yapısıdır." ${ }^{15}$ Kurumsallaşma ise bu sosyal kalıp, rol ve ilişki yapısının standart hale getirilmesidir.

18. yüzyıl sonlarından itibaren modernleşme ve modernleşmenin rasyonelleştirici etkisinde olan Osmanlı Devleti'nde ve müziğinin kültürel üretim sahasında büyük değişmeler yaşanmaktadır. Türk müziğinin özellikle aktarım, nazariyat ve icra geleneğinde dönüşümlerin

11 Refik Ahmet Sevengil, Türk Tiyatrosu Tarihi (İstanbul: Alfa Yayınları, 2014), 707.

12 Sevengil, Yakın Çağlarda Türk Tiyatrosu, 101.

13 Ayr. bil. için bk. Emine Koca, “18. ve 19. Yüzyıl Osmanlı Erkek Modası”, Türk-İslâm Medeniyeti Akademik Araştırmalar Dergisi (2009), 63-81.

14 Sevengil, Yakın Çağlarda Türk Tiyatrosu, 102.

15 Joseph Fichter, Sosyoloji Nedir?, çev. Nilgün Çelebi (Konya: Selçuk Üniversitesi Fen Edebiyat Fakültesi Yayınları), 111. 
yaşandığı bu süreçte, değişmenin modern eğitim kurumları eliyle yeniden inşâ edilmesi ve Türk müziği eğitiminin kurumsallaşması fikri oluşmaya başlamıştır.

Türk müziği öğretimi ve repertuvarının aktarımı alanındaki boşluğu doldurmakla ilgili ilk girişim 1. Dünya Savaşı’nın başladığı tarihlerde (1914) Abdülkadir Töre (1873-1946) tarafından gerçekleştirilmiştir. Yetiştirdiği öğrenciler ve eğitimci tarafıyla da tanınan Töre, okullarda verilen müzik eğitiminde "milli müzik eğitimi” konusunun eksikliğini Maârif-i Umûmiyye Nezâreti ${ }^{16}$ 'ne layiha [tasarı] olarak bildirmiş ancak savaş koşulları nedeniyle bu girişim ilk etapta bir cevap bulamamıştır. Türk müziği eğitiminin bir kurum altında verilmesi gerekliliği fikrini hızlandıran olay ise Almanya'dan gelen bir müzik grubunun, Hilal-i Ahmer Cemiyeti yararına verdiği konserlere, Osmanlı Devleti'nin bir jestle karşılık vermek istemesi ile başlamıştır. Dönemde, alafranga müzik alanındaki tek icra grubu olan Muzıka-yı Hümâyun'dan seçilen bir grup Almanya'ya konser vermek üzere gönderilmiştir. Ancak grubun icrası, Batı müziğinin kendi üretim sahasında beğenilmemiş ve kendilerinden Türk müziği eserleri çalmaları istenmiş; icra grubu ihtisas alanları olmayan Türk müziğinden birkaç eser çalsa da daha fazla eser icra etme konusundaki istekleri yerine getirememiştir. Bu durum İstanbul'da duyulunca Türk müziği eğitimin kurumsallaşması için bir okul açılması gerekliliği gündeme gelmiştir. Töre'nin layihaları bu olay sonrasında cevap bulmuş ve konuyla ilgili çalışmalar başlamıştır. ${ }^{17}$

Türk eğitim tarihi alanındaki en kapsamlı eserlerden birini kaleme alan Osman Nuri Ergin (1883-1961), müzik alanının dışından biri olarak, Dârülelhan'ın açılması ile ilgili şunları söylemiştir. "İşte devletin umumî harp gibi bir ölüm-dirim işiyle uğraştığı, tahsil çağında bulunan bütün gençlerin askere alınarak mekteplerin boşaltıldığı bir sırada bir zevk, bir lüks, bir eğlence işi sayılan musiki ile uğraşılmasının ve binbir ihtiyaç arasında bir musiki mektebi açılmasının sebebi bu mahcubiyet ve bu bapta hissedilen ihtiyaç ve zarurettir."18

Türk müziğinin kurumsallaşması gerekliliği üzerine Maârif-i Umûmiyye Nezâreti bir müzik okulu açmak üzere çalışmalara başlamıştır.

\section{4. İlk Dönemde Dârülelhan'da Verilen Eğitim ve Geleneği Dönüştürme Çabaları}

Türk müziği alanında bir okul kurulmasına ilişkin çalışmalar sonucunda Maârif-i Umûmiyye Nezâreti'nin kurduğu “Musiki Encümeni”nin hazırlamış olduğu talimatnâme ile, erkeklere ve kadınlara ayrı ayrı binalarda eğitim vermek üzere, nağmeler evi anlamına gelen, "Dârülelhan" adıyla bir müzik okulu açılmasına karar verilmiştir. ${ }^{19}$

Okula, Dârülelhan ismi, dönemin saygın bürokratları arasında sayılan, Nişantaşı'nda bulunan konağını, düzenlediği musiki sohbetleri ve meşkler ile dönemin önemli bir musiki merkezi konumuna getiren Ziya Paşa (1849-1929) tarafından verilmiştir. Kuruluş aşamasında

16 Osmanlı Devleti’nde eğitimle ilgili işleri sürdüren bakanlık düzeyindeki kurumdur.

17 Ayr. bil. için bk. Ergin, Türkiye Maarif Tarihi.

18 Ergin, Türkiye Maarif Tarihi, 1579.

19 Dârülelhan adıyla ilgili detaylı bilgi için bk.: Okan Murat Öztürk, "Dârû'l-elhan” İsmindeki Sır: "Jeune" Ütopyacılığa Dair Bir Sembol”, Kuruluşunun Yüzüncü Yılında Dârü'l-Elhân'a Armağan içinde, haz. Gülçin Yahya Kaçar (Ankara: Atatürk Kültür Merkezi Başkanlığı, 2018), 235-289. 
Ziya Paşa Musiki Encümeni'nin başkanı, Ali Rifat Bey ikinci başkan, Zekaizade Ahmed Efendi (1869-1943) ve Tanburi Cemil Bey de aza olarak görev almışlardır. Dârülelhan'ın öğretim kadrosunda ise Musiki Encümeni'nde ismi geçen kişiler dişında Andon Efendi (?-1915), Leon Hanciyan (?-1947), Gomidas Efendi gibi dönemin önemli müzisyenleri yer almaktadır (Özden, 2019, s. 67).

Takvim-i Vekâyi'de yayınlanan "Mûsikî Encümeni ve Dârülelhan Talimatnamesi ile Dârülelhan Programı"nın ilk maddesinde kurumun ve encümenin amacı "mûsikî sanatının ilmî bir sûrette talim ve tedrisi ve mûsikîye ait âsâr-1 mutebere-i eslâfın neşr ve ihyâsı" olarak özetlenmiştir ${ }^{20}$. Musiki Encümeni ve Dârülelhan'ın ortak amacı müzik sanatının bilimsel şekilde uygulamasının ve öğretiminin yapılması; eski eserlerin kayıt altına alınıp yayılması ve yeniden canlandırılması olarak belirtilmiştir. Aynı talimatnamenin 3. maddesinde kurum ve encümenin görevi daha detaylı olarak açıklanmaktadır. Bu maddeye göre encümenin asıl görevi musiki sanatının okullarda bilimsel olarak öğretilebilmesi için 'edvar'lardaki yani eski musiki kitaplarındaki kuralları toplayıp, birleştirip nazariyat olarak öğretmek ve ayda ya da iki ayda bir eski müzisyen/teorisyenlerin ihyasına yönelik risale neşretmektir. Hem eski eserlerin üzerinde çalışılması hem de o dönemden önceki müzik çevrelerinin tanıtılmasının amaçlanması; bir literatür oluşturma çabası içermesi bakımından önem taşımakla beraber, sözlü kültürle aktarımı gerçekleştirilen Türk müziği’nin yazılı kültüre geçişi için de büyük önem taşımaktadır. Bununla birlikte kurumun içtüzüğünde, eğitimin nota ile yapılması gerektiğini önemle vurgulayan maddeler de yine aynı amaca hizmet etmektedir. Dârülelhan'da nitelikli öğretmenler yetişmesini sağlamak, kurumun ders programını ve bütçesini düzenlemek, Dârülelhan'da 'mükemmel' bir müze ve kütüphane oluşturmak encümenin ve kurumun görevleri arasında sıralanmaktadır. Encümenin aynı maddede sayılan son vazifesi ise "Osmanlı musikisinin zamanın zevk ve mizacına göre istihalesinde [değişiminde] mahiyet-i mahsusasını [kendine has özünü] muhafazaya muktedir sanatkârlar yetiştirmektir" şeklinde belirtilmiştir. Kurumun, eski nazariyat kitaplarından faydalanmakla birlikte; müziğin dönemin şartlarına göre değişimi konusunda muhafazakâr bir bakışa sahip olmadığı görülmektedir. Hatta amaç olarak bu değişimi, musikinin kendi özel mahiyetlerini koruyarak devam ettirmek suretiyle yönlendirmeye çalıştığı anlaşılmaktadır. Dolayısıyla Dârülelhan'da verilmesi planlanan eğitimin diyalektik bir yapı içerisinde şekillendiği görülmektedir. Burada verilecek eğitimle öğrenciler hem eskinin ve o günün müziğini, teorisini bilip aktaran hem de bunları dönüştürücü, dönemin ruhuna ve gerekliliğine uyarlayacı aktörler olarak konumlandırılmak istenmektedir. Bu durumda -dönüştürücü aktörleri yetiştiren- Dârülelhan'ın da müziğin kültürel üretimi alanında, sistemin yeniden üretiminin önemli ve bütünleyici bir parçası haline gelmesi beklenmektedir.

20 Talimatname ve programının tamamının çevirisi için bk.: Ahmet Kara, Kuruluşunun 100. Yllında Darülelhan (İstanbul: İstanbul Büyükșehir Belediyesi, 2018).

Erhan Özden, Osmanlı Devleti'nin Konservatuvarı Dârülelhan (Arşiv Belgeleriyle) (Ankara: Atatürk Kültür Merkezi Başkanlı̆̆ı, 2019).

Kolukırık, Türk Müzik Tarihinde Dârü'l-Elhân ve Dârü'l-Elhân Mecmuası. 
Dârülelhan aynı yönetmelikte dört yıllık planlanmış, kadınlar (inâs) ve erkekler (zükûr) şubelerinden oluşan, şubeleri iki farklı binada eğitim veren "tarihşinas ve musiki sanatına vâkıf ve beste tanzimine muktedir ve hakiki sanatkâr namına ihraza [nail olmaya] şayeste [uygun] muallim ve muallime" yetiştiren bir müzik okulu olarak tanımlanmaktadır. Yönetmeliğe göre, şubelerin ikisinin de müdür ve müdüre olmak üzere ayrı yöneticileri bulunacaktır; bu kişiler kendi şubelerinden birinci derecede mesul olacaklardır. Farklı yöneticilerle yönetilecek şubelerin eğitim programında ise herhangi bir cinsiyet ayrımı gözetilmemiş; iki şubenin öğrencilerine de aynı programın uygulanacağı belirtilmiştir.

Öğrencilere ilişkin yönetmelik maddelerine bakıldığında, öğrencilerin Dârülelhan'a kabulünde 'gerek musikiye istidatı ve gerek ailece mazbût'ül-hâl bulunması' hususlarının önemi vurgulanmıştır. Yönetmelikteki bu maddelerden yola çıkarak, eğitimin -bilhassa E. Durkheim (1858-1917)'ın düşünceleri gibi- işlevselci bir bakış açısı ile yapılandırıldığını söylemek mümkündür. Durkheim'ın eğitim ile ilgili fikirlerine genel olarak bakıldığında, eğitimi bir sosyalleştirme olarak ele aldığı görülmektedir. Bu nedenle de eğitim, toplumun ihtiyaçları doğrultusunda şekillenmeli ve toplumun devamlılığının sürdürülmesi adına ortak değerler, ahlak, sosyal normlar gibi toplumsal unsurlar, eğitimle yeni kuşağa öğretilmesi gereken temel unsurlar olmalıdır. ${ }^{21} \mathrm{Bu}$ işlevselci yaklaşımla Dârülelhan'da, öğrenci alımında hem öğrencinin hem de ailesinin toplumsal normlara uygunluğu müzik yeteneği ile aynı önemde değerlendirilmiştir.

Öğrenci alımı için gerekli şartlar; iptidai mektep tasdiknamesine sahip olmak ve hanendeler için on beş yaşından küçük, sazendeler içinse yirmi yaşından büyük olmamak olarak belirlenmiştir. Ancak sonraki yıllarda yaş sınırı şartı esnekleşmiştir. Alınan öğrenciler de 'müptediler' yani acemiler ve ' az çok musikiye aşina olanlar' olmak üzere ikiye ayrılırlar. 'Az çok musikiye aşina olanlar' encümen huzurunda yapılacak bir seviye sınavıyla uygun sınıfa kaydedilecek ve bu öğrenciler için -henüz açılan okulda- ayrıca yeni ders saatleri belirlenecektir.

Bahsedilen eğitim misyonlarının yanında, eski eserlerin yaygınlık kazanması için Dârülelhan'da oluşturulacak kadın ve erkeklerden oluşan fasl-1 umûmî heyetleri ve heyetin konserlerinden elde edilecek gelirlerin dağıtımı yönetmelikle planlanmıştır. Bu yönetmeliğe göre fasıl heyetlerine -tüm heyetin sayısı $125^{\prime}$ i geçmemek şartıyla- Dârülelhan öğrencileri dışında yetenekli, haysiyetli ve itibarlı kişiler dahil olabileceklerdir. Fasl-1 umûmî heyetlerinin yönetmelikle planlanması, Dârülelhan'ın sadece bir eğitim kurumu olmadığının; aynı zamanda sanat kurumu olarak ele alındığının göstergesi olması bakımından önemlidir. Aynı zamanda bu fasl-ı umûmî heyetlerinin çalışmaları ve konserleri ile kurumdaki müzik anlayışının mesleki sosyalleşme yoluyla yaygınlaştırılmaya çalışıldığı da anlaşılmaktadır.

Yönetmeliğin 41. maddesine göre Dârülelhan'da mansur ahengi kabul edilmiştir. Bu ahenge göre dügâh perdesi, tıpkı Batı müziğinde olduğu gibi $440 \mathrm{~Hz}$ frekansa akort edilir. Bu tercihin, Batı müziği ile Türk müziğini birbirine adapte etmek ve çalgıların beraber icrasını

21 Émile Durkheim, “İlm-i Terbiye ve İçtimaiyat”, İstanbul Üniversitesi Sosyoloji Dergisi 1/5 (2014), $207-224$. 
mümkün kılabilmek için yapıldığı düşünülebilir. Ancak alınan bu kararın, bilhassa inici özellik gösteren makamların icrasında yaratacağı zorluk nedeniyle Türk müziği ile ilgilenenlerce yadırganmış olduğu, Mehmed Bahâ (1877-1953) tarafından Âlem-î Mûsikî dergisinde yazılan yazıda açıç̧a belirtilmiştir.

“En ziyâde beynime dokunan madde, Dârü'l-Elhân'da piyano âhenginin resmen kabûl edilişinin ilânı idi. Bizde hiçbir zaman hânendelerin sesleri derecesi nazar-1 dikkate alınarak bir şarkı yapılmamış olduğu halde muhayyer, şehnâz ve daha diğer fasılların bu âheng ile okunması için ne gibi bir sihr ve kerâmet gösterileceğine garîbâne intizâr etmekte iken vaad ve ilân edilen ahengde devam kâbil olmayıp nihâyet bizim bildiğimiz perdelere inildiğini yani transport çalındığını orada bulunan zevâttan işittim." ${ }^{22}$

Aynı yazıdan, Dârülelhan'daki icraların mansur ahengi ile yapılamadığı, bu kararın yönetmelik üzerinde kaldığı duyumu da aktarılmıştır.

Dârülelhan’ın yayımlanan "Dârülelhan Programı” başlıklı ders planları, dört sınıf için ayrı ayrı hazırlanmıştır. Programa göre öğrencilere nota, solfej, usul öğretimi, ilâhiyat ve âyin-i şerif, müzik tarihi, bestekârlık ve çalgı derslerinin eğitimi verilecektir. Ders içerikleri ile detaylı bilgi verilmemiştir. Programa bakıldığında gam natürel, gam modere, vals, çeyrek ses gibi Batı müziği terimlerinin kullanılması dikkat çekicidir. Bazı terimler ise kübra: majör, sagîr: minör, mücirad (solfej) örneklerinde olduğu gibi açıklamalı olarak yazılmıştır. Bu yazımlardan Musiki Encümeni'nin terminoloji konusunda net bir kararının olmadığı ve Türk müziği alanında terminoloji ihtiyacının olduğu sonucu çıkarılabilir. ${ }^{23}$

Dârülelhan'ın kuruluşundan yaklaşık iki buçuk yıl sonra, 1919 yılında erkekler kısmının bina sahibi, kirasının ödenmediği gerekçesi ile mahkemeye başvurup, binanın boşaltılmasını talep etmiştir. Mahkemenin 14 Temmuz tarihinde, binanın tahliyesine karar vermesiyle, bina terk edilmiştir. Musiki Encümeni başkanı Ziya Paşa, eğitimin kadınlar kısmında ayrı günlerde, dönüşümlü olarak devam edebileceğini belirtse de, bu fikir toplumsal cinsiyet algısı nedeniyle, Maarif Nezareti tarafından reddedilmiştir. Erkekler kısmındaki öğreticilerin bazıları kurum içinde farklı görevlere getirilmiş, bazılarının maaşları kesilmiştir. Kesilen maaşlar ileride erkekler kısmı tekrar eğitim vermeye başladığında kullanılmak üzere tutulmuştur. Bu durum erkekler kısmının tekrar açılması niyetinin kaybolmadığının göstergesidir. ${ }^{24}$ Erkekler şubesinin kapatılmasının tarihi ile ilgili bir arşiv belgesi bulunamadığ için, hangi tarihte kapatıldığ ile ilgili net bilgiye ulaşılamamaktadır. Ancak Mehmed Bâha, 1 Teşrin-i evvel 1335 (1 Ekim 1919) tarihinde, Âlem-î Mûsikî dergisinde yayımlanan "Dârü'l-elhân'ın Lağvı” başlıklı yazısında konuya yer vermiştir. Yazısında kurumun lağvı ile ilgili basındaki ve kamuoyundaki tepkisizlikten yakınan Mehmed Bâha; Dârülelhan'ı denetleyen uzmanların, uygulanan talimatname nedeniyle kurumu kapattıklarını ve ileride yeni talimatnamenin hazırlanması ile yeniden açılacağını

22 M. Beste Aydın, Âlem-i Mûsikî (Çevriyazım ve inceleme) (Yüksek Lisans Tezi Ege Üniversitesi, 2004), 32.

23 Dönemin terminoloji meselesi ile ilgili bk.: Nilgün Doğrusöz, "Hüseyin Sadeddin Arel'in Kaleminden Musiki Terimleri Meselesi”, 2017 Arel Sempozyumu Bildirileri içinde, (İstanbul: Türkiyat Araştırmaları Enstitüsü, 2018), 193-211.

24 Kara, Kuruluşunun 100. Yllında Darülelhan, 41-42. 
vadettiğini aktarmaktadır. ${ }^{25}$ Talimatnamenin 10. maddesinde, iki şubenin ayrı ayrı binalarda eğitim vereceğinin ifade edilmesi, denetleyicilere göre, aynı binada eğitim verilmesinin önüne geçmiştir. Bu yazıda, yaşanan durumun “Dârü'l-Elhân'ın yer bulunmadı̆̆ı bahânesiyle lağvedileceği şâyiası [söylentisi]” olarak anlatılması da Temmuz ayında binadan ayrılan şubenin, Ekim ayında henüz resmi olarak lağvedilmemiş olduğunun göstergesidir. Binası olmadığ için eğitim verilememiş olsa da; şube, 1919'un Ekim ayında resmi olarak halen açıktır.

Çeşitli yazılı kaynaklarda Rauf Yekta Bey’in, bu ilk dönemdeki kurumsal yapı içinde yer aldığı bilgisi tekrarlanmaktadır. Ancak, bilgiler ışığında, Rauf Yekta Bey, 1922 yılına kadar Divan-1 Hümâyun' da ${ }^{26}$ çeşitli görevlerde bulunmuş ve buradan emekli olmasının ardından, Dârülelhan’ın ikinci yapılanma döneminde kurumda ders vermeye başlamıştır.

Bu bilgi, incelenen yönetmeliğin yayınlamasının üzerinden yaklaşık iki yıl sonra Rauf Yekta Bey'in Şehbal dergisinde, Dârülelhan ile duyumlarını aktadığg yazısından da açıkça anlaşılmaktadır. Rauf Yekta Bey, Dârülelhan ile ilgili şu bilgileri aktarmaktadır:

"Mûsikî encümeninin teşekkülünden beri iki sene olduğu, Dârülelhân'ın sene-i devriyye-i küşâdının hulûlüne de pek az bir zaman kaldığı halde ne encümenin tarz-1 mesâisine ve ne de mektebin küşâd ve derslere mübâş̧eret edildiğine dâir bir şey işitilmediğinden hasbelmerak bu bâbda biraz tahkîkât icrâ ettik. Aldığımız malûmâta nazaran Dârülelhân'ın küşâdını müteâkib birinci sınıfı bi’t-teşkil müretteb programa tevfîkan tedrisât-1 icrâsı icâb eder iken, şimdiye kadar derslere başlanamamış ve yalnız fasl-1 umûmî nâmı verilen heyete kırk kadar hânende ve sâzende kaydedilerek bunlara yegâh ve şehnaz buselik fasıllarının meşkiyle vakit geçirilmekte bulunmuştur."27

RaufYekta Bey'in bu yazısından, Dârülelhan'da ilk iki yıl, fasıl heyeti çalışmaları dışında yönetmelikte belirtilen eğitim planının uygulanamadığı anlaşılmaktadır. Aynı yazısında Yekta, Dârülelhan'daki öğrencilerin durumunu

"Maahâzâ [bununla beraber] arası çok geçmeden meşkhâne usûl-i kadîmesinde dümtekzen olmaktan bir şey istifade edilemediğini talebe pek âlâ anlamış ve programı mûcibince [gereğince] tedrisâta başlanmasından da kat'-1 ümid etmiş olmalı ki birer ikişer devamdan vazgeçenler çoğalmış ve bu hâlin neticesi olarak Dârülelhân'ın zükûr [erkek] kısmındaki talebenin adedi dört beş kişiye tenzil etmiştir..... Dâr-1 mezbûrun [sözü edilen yerin] inâs [kadın] kısmındaki tâlibâtın adedi binnisbe daha çok olduğu işitilmekte ise de tahkîkimize nazaran orada dahî program dâhilinde bir gûne tedrisat icrâsı olmayıp yine 'meşkhâne' usulünde ve alel-ekser güfteleri bazı parçalar meşk edilmekte, biraz da nota ve âlât-1 mûsikîyye dersleri verilmekte imiş."

şeklinde aktarmıştır. Dârülelhan'da verilen eğitimi meşkhane eğitimine benzeten Yekta, kurumun bu nedenle öğrenci kaybı yaşadığını belirtmiştir. Yazılı kültür ürünü olarak değerlendirilebilecek

25 Aydın, Âlem-i Mûsikî (Çevriyazım ve inceleme), 168.

26 Osmanlı devlet yönetiminde XV. XVII. yüzyılın ilk yarısına kadar en önemli karar organıdır. 'Padişah Divanı' anlamına gelmektedir. Devletin genel yönetiminden, hukuki, siyasi, idari, mali ve askeri faaliyetlerinden sorumludur. [Ahmet Mumcu, "Divan-1 Hümayun", Türkiye Diyanet Vakfi İslam Ansiklopedisi. c. 9, (İstanbul: TDV Yayınları, 2000), 431.]

27 Mehmet Öncel, Rauf Yektâ Bey'in Âti, Yeni Mecmûa, Resimli Kitap ve Şehbâl Adlı Mecmûalarda Mûsikî ile İlgili Makalelerinin İncelenmesi (Yüksek Lisans Tezi, Marmara Üniversitesi, 2010), 30.

28 Öncel, Rauf Yektâ Bey’in Âti, Yeni Mecmûa, Resimli Kitap ve Şehbâl Adlı Mecmûalarda Mûsikî ile İlgili Makalelerinin İcelenmesi, 31. 
talimatname ile programın varlığına rağmen, kurumdaki eğitimin bu program gereğince uygulanamaması ve programda planlanan standartlaşmanın, eğitime yansıtılamamış olması nedeniyle; Dârülelhan ile ilgili, sözlü kültürle aktarılagelmiş Türk müziğinin, en önemli öğretim merkezlerinden olan meşkhane benzetmesinde bulunması, Rauf Yekta Bey'in kurumda verilen eğitimin ciddiyetine inancının olmadığının açık göstergesidir.

Mehmed Bahâ ise Dârülelhan ile ilgili duyumları sonrasında düşündüklerini şu şekilde aktarmıştır: "Bir çoğu müstesnâ olmak şartıyla mezkûr [adı geçen] mektepte hiçbir zaman katiyen bir yenilik ihtiyâcı hissedilmediği gibi muallim sayılamayacak toplama çalgı ustalarından bir kaçının da oraya devamını anlayınca bu iş, havanda su dövmekten başka bir şeye benzemeyecek demiştim. ${ }^{" 29} \mathrm{Bu}$ ifadeler de Rauf Yekta Bey'in sözlerini yinelemekte; verilen eğitimin, programda aktarılanla örtüşmediği ve herhangi bir yenilik çabasına girmeden eski usulde devam ettiği fikrini desteklemektedir.

Musiki Encümeni'nin kuruluş aşamasında ikinci başkan, Dârülelhan'da ise başkan yardımcısı olarak görev alan fakat sonra kurumdan istifa eden Ali Rifat Çağatay'ın Süleyman Cevad ile yaptığı mülakattaki

“Dârülelhan'ın maksad-1 teşkili daha büyük gayelere matuf idi. Ancak, yekûn tahsisatı ile mektep kirasını ve bir-iki muallimin maaşını güçlükle temin edebilen bir müesseseden daha büyük muvaffakiyetler istihsaline imkân olamayacağına kanaatim hasebiyle daha bidayette çekilmiş idim. Mektebin zukûr kısmının açılamaması ve ders programının tamamen tatbik edilememesi kanaatimi teyit etmiştir."

ifadeleri, kurumla ilgili yaşadığı hayal kırıklığı ve ders programlarının düzgün uygulanamadığının başka bir göstergesidir.

Dârülelhan'da ders programının tam anlamıyla uygulanmaması ile birlikte; faslı-1 umûmî heyetinin yaptıkları konserler de, zaman zaman basında sazlardan bazılarının yeterince iyi çalınmadığı, faslın idaresizliği ile ilgili olumsuz eleştiriler almıştır. ${ }^{30}$ Bu konserlerle ilgili Servet-i Fünun dergisinde çıkan bir yazıda ise "...müsamereyi idare etmek isteyen Muallim İsmail Hakkı Bey'in orkestra usulü el jestlerini alaturka musikiye karşı yabancı gördük." ${ }^{31}$ denilmektedir. Bu ifadelerden, Dârülelhan'da gerçekleştirilmeye çalışılan yeniliklerin müzik çevrelerince yadırgandığını söylemek mümkündür. Aynı yazıda iyi bir musikişinas olduğu belirtilen -Sultan Vahdettin'in kızı- Ulviye Sultan (1892-1967) ve bazı diğer sultanların konsere geldiği bilgisi verilmiştir (EK-1). Bu bilgi, Osmanlı hanedanının Dârülelhan'ın faaliyetlerini takip ettiğini anlatması bakımından önemlidir. Konser programlarına bakıldığında, konser bölümlerinin çoğunlukla makam fasılları olarak oluşturulduğu görülmektedir. Ancak bu fasıllar, klasik fasıl sıralamasına uygun olarak düzenlenmemiş; fasıllara şarkılar eklenmiş ve çoğunlukla Türk müziğinin en büyük ve sanatlı türü olan kâr türü çıkartılmıştır. Fasıllar, dönemin müzikal beğeni anlayışına göre düzenlenmiştir.

29 Aydın, Âlem-i Mûsikî (Çevriyazım ve inceleme), 168.

30 “Dârülelhan'ın İkinci Konseri”, Vakit, 12 Eylül 1918, 2

31 “Dârülelhan Müsameresi”, Servet-i Fünun, 12 Eylül 1918, 1410/96. 
Dârülelhan konserlerinde, kadınların sahneye çıkması da zaman zaman sorunlara neden olmuştur. 1922 yılında Şehzadebaşı'nda verilen konser nedeniyle dönemin İstanbul Valisi’nin, Dahiliye Nezareti'ne yazdığı yazı, bu duruma örnek gösterilebilir. İzin başvurusu yapılmaksızın gerçekleştirildiği belirtilen konserde; kadınların, erkeklerin önünde şarkı söyleyip, çalgı çalmalarının dine ve ahlaka aykırı bulunduğu belirtilmiştir. ${ }^{32}$ Polis müdüriyeti de aynı sebepten Dahiliye Nezareti'ni, Maarif Nezareti'nin uyarılması hususunda ikaz etmiştir. ${ }^{33}$ Osmanlı Devleti’nde kadın eğitimine baktığımızda, Tanzimat dönemine kadar kadınların sıbyan mekteplerine gidebildikleri ve daha fazla eğitim almalarına gerek duyulmadığı görülmektedir. Sadece seçkin sınıfa mensup ailelerin kızları, özel derslerle, konak eğitimi sistemiyle eğitimlerine devam edebilmişlerdir. Tanzimat döneminin, kadınlar açısından en önemli getirisi, ilkokuldan yukarı düzeyde eğitim alabilecekleri rüştiyelerin açılmış olmasıdır. II. Meşrutiyet döneminde ise kadın eğitimi ve kadın hakları üzerine tartışmalar hız kazansa da; artan milliyetçi söylemlerin de etkisiyle kadın eğitimi, milli duygularla büyümesi gerektiği düşünülen çocukları yetiştirmek ve bu sayede toplumun yeniden şekillenmesini sağlayabilmek adına önem taşımaktadır. İkincil olarak ise, kadınlara yönelik okulların artmasıyla, bu okullarda eğitim verilebilmesi için öğretmen yetiştirilmesi bakımından kadın eğitimi önem arz etmektedir. Bu süreçte şekillenen, kadın eğitimine yönelik toplumsal cinsiyet algısıyla Dârülelhan'a baktığımızda ise, kadınların müzik eğitimi verilen bir okulun talebesi olmaları, şarkı söyleyip, çalgı çalmaları sorun teşkil etmezken; aldıkları eğitimin uygulamasını sahne üzerinde yapmaları ahlaka aykırı bulunarak, dönem anlayışı çerçevesinde kadınların okuldan kazanımları muallime olmakla sınırlandırılmıştır. Bununla birlikte Dârülelhan'ın kuruluş aşamasında, kurumun öğretmen yetiştirme misyonunun da olması nedeniyle Dârülmuallimîn ile işbirliği talebinde bulunan Ziya Paşa'ya, Dârülmuallimîn yönetimi tarafından verilen yanıt olumsuz olmuştur.

"İbtidai Dârülmualliminlerin müzik tedrisatında hedefledikleri gaye öğretmen adaylarına iyi ve tam nota öğretmek (solfej) müzik nazariyatını göstermek ve bunları herhangi bir besteyi, notasını kolaylıkla okuyabilecek bir hale getirmek, sesleri tabii ve fennî kabiliyet ve taksimata göre tanzim, tesviye ve tazyif eylemek, teknik ve pratik metodlarla gına muallimi yetiştirmekten ibarettir. Binaenaleyh 'hanende ve sazende' yetiştirmek isteyen Dârülelhan ile mekatib-i ibtidaiyyede nota ve gına tedrisi usulleri öğrenmekle mükellef Darülmualliminler arasında münasebet tasavvur doğru değildir." ${ }^{\text {34 }}$

Burada Dârülmuallimîn yönetimi, İbtidai mektepte müzik dersleri verecek öğretmenin ve Dârülelhan öğrencilerinin aldığı eğitimin farkını açıklayıp, alanları ile ilgili sınırlar çizerken; Dârülelhan'da eğitim alan kadın öğrencilerin sahasını daha da daraltmaktadır. Müzik alanında sahnede olması ahlaka aykırı bulunan ve sadece muallime olarak kendine yer bulması beklenen kadınların, iptidai mekteplerde öğretmenlik yapmasının da -aldıkları eğitim nedeniyle- önünün kesilmek istendiği ve bu bilgiler ışı̆̆ında, mezun olan kadınların, Dârülelhan'dan edindikleri kültürel sermayeyi sadece hanende ve sazende yetiştirmede kullanabilmeleri istenmektedir.

32 Başbakanlık Osmanlı Arşivi (BOA), Dahiliye (DH) EUM.AYŞ 58/123, 30-05-1340 (29 Ocak 1922).

33 Başbakanlık Osmanlı Arşivi (BOA), Dahiliye (DH) EUM.AYŞ 58/123, 30-05-1340 (29 Ocak 1922).

34 Akt. Kolukırık, Türk Müzik Tarihinde Dârü'l-Elhân ve Dârü'l-Elhân Mecmuası, 26. 
Yönetmeliklerinden ve konserlerinden Türk müziği ağırlıklı bir eğitim verdiği görülen Dârülelhan'la ilgili, 19 Mart 1918 tarihli Meclis-i Ayan tutanaklarında kayıt altına alınan tartışma, kurumda verilen eğitim ile ilgili konuşmaların içeriği açısından dikkat çekicidir. Dârülelhan ve Musiki Encümeni'ne verilecek ödenekle ilgili konuşmada dönemin Nafia Nazırı ve Maarif Nazırı Vekili -bayındırlık ve eğitimden sorumlu nazırı- Ali Münif Bey (18741951), Dârülelhan ve Musiki Encümeni’ni vekillere tanımlamıştır. Dârülelhan'1 “Dârülelhan, birisi zükûra, diğeri inasa ait olmak üzere, iki kısma münkasımdır. Bunların talimatnameleri, programları mevcuttur. Her biri dörder sınıf üzerine müesses musiki mektebidir. Orada musikinin ta elifbasından başlayarak ilânihaye lâzım gelen şeyler, talim ve tedris olunuyor ve lâzım gelen alât ve edavat ile de tatbikat yapılıyor. Bu suretle musiki-i millî halinde devam ediyor.”; Musiki Encümeni’ni ise "Bir de Garp ve Şark musikisini mevz ve telif ederek, yeni bir musiki vücuda getirmek için çalışılıyor. Bu mesele Dârülelhanın vazifesi dahilinde değildir. Bunun için Musiki Encümeni namı altında bir Encümen teşkil edilmiştir. Gerek Garp ve gerek Şark musikisine vakıf olan zevat bir komisyon halinde içtima ediyorlar. Bu vazife ile bunlar mükelleftir.” şeklinde vekillere anlatmıştır. Nazır, Dârülelhan’ı müzik ile ilgili bir eğitim kurumu olarak aktarırken; encümeninin görevini Garp ve Şark müziğini birleştirerek yeni bir müzik oluşturmak olarak tanımlamıştır. Bu tutanak konuşmasından bir yıl önce yayımlanan Dârülelhan talimatnamesinde ise Musiki Encümeni’nin görevi; müzik sanatının bilimsel şekilde öğretiminin yapılması, eski eserlerin kayıt altına alınıp yayılması ve yeniden canlandırılması olarak belirlenmiş iken, bu konuşmada bu görev tanımı belirlenenden tamamen farklı şekilde aktarılmıştır. Dolayısıyla, Musiki Encümeni’nin görev tanımının bir yıl içinde büyük bir değişsime uğradığı görülmektedir. Mahmud Paşa isimli vekilin, Dârülelhan'da hangi tür müzik tahsil ettiklerine dair sorusuna Ali Münif Bey'in verdiği yanıt, kurumda verilmesi planlanan eğitimi açıklaması bakımından önem teşkil etmektedir. Bu soruya cevaben "Şimdilik mevcut olan musikiyi, yani bizim musikiyi tahsil ediyorlar. Bunun için teşkil olunan Encümen, tetkikatını ekmal edip Dârülelhan'da tedris ve talim olunacak usulü tebliğ edinceye kadar bu usulde devam edecekler.” demiştir. Bu konuşmalar, Dârülelhan'ın eğitimi ile ilgili yeni bir program ve eğitim planı üzerinde çalışıldığı, Dârülelhan'nın ikinci yapılanmasında verilecek eğitimin benzerinin, 1918 yılından planlanmaya başlandığının göstergesidir. İkinci yapılanmadaki eğitimin sosyolojik nedenleri olarak değerlendirilen Cumhuriyet dönemi müzik politikaları ve milli musiki tartışmaları henüz gündemde değilken; bu planlamanın konuşulması, dönemin Batılaşma politikalarının müzik üzerindeki etkisini göstermesi bakımından çok büyük önem taşımaktadır.

Kurumun içeriğinin değişmesi ile ilgili çabaların olduğuna dair bir başka veriyi ise Muhiddin Sadak’ın (1900-1982) anılarından öğrenmekteyiz. Muhiddin Sadak “1922 yılında 40 lira maaş ile Dârülelhan'da göreve başlamıştım, düşman memleketi terk etmek üzereydi. Önce bir trio kurmuştuk. O sıralarda yalnız alaturka tetrisat yapan Dârülelhan'da garb musikisi öğretilmesi 
için bir teşebbüs vardı." ${ }^{35}$ şeklinde anlattığı anılarından, kurumda yönetmelik düzenlemesi yapılmamış olsa bile Batı müziği eğitimi ile ilgili girişimlerin olduğu anlaşılmaktadır.

I. Dünya Savaşının etkileri, maddi sıkıntılar vb. sebeplerle erkekler bölümünün kapatılmasının ardından, kadınlar bölümünün sekiz kişilik öğretim kadrosu ile bir süre daha kurumdaki eğitimi devam ettirdiği bilinmekte; kurumun bu dönemdeki eğitiminin sonlanışı ile ilgili kesin bilgilere ulaşılamamaktadır. Başbakanlık Osmanlı Arşivi’nde bulunan 1922 yılının Ekim ayı tarihli belgelerde Dârülelhan'ın kapatılması ile ilgili olarak görüşüldüğü ancak kendi alanındaki tek eğitim kurumu olması nedeniyle kurumun kapatılmamasına ve Avrupa' daki konservatuvarlar gibi konserler düzenleyip bu konserlerden edinilen gelirle kurumun masraflarının karşılanmasına karar verilmiştir (EK-2) ${ }^{36}$ Bu evraklara göre kurum, bu tarihlerde resmi olarak kapatılmamış; ancak -kuruluşunun hemen ardından başlayan ve ilk yapılanma döneminin tamamında yaşanan maddi imkansızlıklarla eğitim vermeye çalışılan- Dârülelhan, kaderine terk edilmiştir.

\section{Cumhuriyetin Kültür Rüzgârı 1923-1926 Yıllarında Dârülelhan'da Verilen Eğitim ve Geleneği Dönüştürme Çabaları}

I. Dünya Savaşı'nın etkileri, Batılılaşmanın etkileri, Osmanlı Devleti'nden Türkiye Cumhuriyeti'ne geçiş dönemindeki kültürel çatışmalar neticesinde Dârülelhan'da bir değişim ihtiyacı hissedilmiştir.

Dönemin Valisi Haydar Bey’in (1879- 1937) desteğiyle girilen yeni dönemde, öncelikle 1923 yılında Musiki Encümeni lağvedilmiştir. Dârülelhan, Maarif Vekaleti’nden ayrılıp İstanbul Valiliğine bağlanmış ve programa Batı müziği şubesi eklenerek yeniden yapılandırılmıştır. ${ }^{37}$

Dârülelhan'ın yeni müdürü olarak görev alacak Musa Süreyya Bey (1884-1932), Vatan gazetesindeki “İstanbul'da Yeni Bir Konservatuvar Açılıyor” başlıklı yazıda, ilk dönem yapılanmasındaki Dârülelhan'da ciddi bir eğitimin verilemediğinin altı çizerken, müziğin bilimsel kısmı ile ilgili yoksunluklar yaşandığı ve müzik alanında ihtiyaç duyulan kurumsal yapının kurulamadığı da aktarmaktadır.

Dârülelhan, 14 Eylül 1923'te Garp ve Şark müziği bölümleri ile -yeniden yapılanarakaçılmıştır. Musa Süreyya Bey Dârülelhan Mecmuası'nda, “Dârülelhan Şu’unu” başlıklı yazıda "Şanlı zaferleri ve mes'ûd inkılâbı müte‘âkib makâm-1 vilâyeti teşrîd eden Vâli-i muhterem Haydar Beyefendi birçok kıymetli icrâ'âtı meyânında Dârülelhân'ın da Avrupa konservatuarları gibi asrî bir müessese olarak vücûd bulmasına sarf-1 himmet buyurdular" sözleriyle kurumun Avrupa konservatuvarları gibi “asri” bir eğitim kurumu olmasının planladığının altını çizmiştir. Aynı yazıda Musa Süreyya Bey Dârülelhan'ın amaçlarını musiki eserlerinin korunması ve unutulmamasını sağlamak, dönemin müzik ilerlemelerini duyurmak, milli musikiyi layık

35 Evin İlyasoğlu, "Melodiler Yuvası. Ne güzel İsimmiş!”, Cumhuriyet, 25 Kasım 1992, 11.

36 Başbakanlık Osmanlı Arşivi (BOA), BEO (Bab-1 Ali Evrak Odası) 4723/354161-1, 04-03-1341(25 Ekim 1922). Başbakanlık Osmanlı Arşivi (BOA), BEO (Bab-1 Ali Evrak Odası) 4723/354161-2, 04-03-1341(25 Ekim 1922).

37 Gönül Paçacı, "Cumhuriyet“in Sesli Serüveni”, Cumhuriyetin Sesleri içinde, (İstanbul: Tarih Vakfı Yayınları, 1999), 13. 
olduğu seviyeye taşımak, yapılacak ilmi toplantılarla eski eserleri kayıt altına almak ve opera, operet gibi sözlü eserleri dilimize uyarlamak olarak sıralamıştır.

Dârülelhan'ın bu döneminde Garp bölümünde müdür olarak Musa Süreyya Bey, müdür muavini olarak da Yusuf Ziya Demirci bulunmaktadır. Dönemin öğretim kadrosu şu şekildedir: Alafranga bölümünde; Zeki Bey (Orkestra şefi), Ekrem Besim Bey, Cemal Reşit Rey (19041985), Nimet Vahid, Chevalier Geza de Hegey, Victor Radeglio, Edgar Manas, Henry Fourlani, Sadri Bey, Zati Bey, Nezihe Hanım, Muhittin Sadak Bey, Kadri Bey, Veli Bey (Kanık), Adil Bey, Osman Şerefeddin Bey, Seyfi ve Sezai Asal kardeşler, Ali Bey (Sezin), Mesud Cemil Bey. ${ }^{38}$

Şark Musikisi bölümünün kadrosunda bulunanlar ise; Nuri Bey (Duyguer), Kevser Hanım, Mustafa Bey (Sunar), Sedad Bey (Öztoprak), Hayriye Hanım (Örs), Faika, Zehra, Şeref Hanımlar, Muazzez Hanım (Yurcu), Ziya Bey, Refik Bey, Faize Hanım (Ergin), Emin Bey (Yazıcı), Ruşen Ferit Bey (Kam), Rauf Yekta Bey, Zekaizade Hafız Ahmed Bey, İsmail Hakkı Bey, Teganni: Ziya Bey, Zahide Hanım idi. Bu kadroya daha sonra Reşat Bey (Erer) ve Dürrü Bey de katılmıştır (Resim 1). ${ }^{39}$ Batı müziği bölümünün eğitim kadrosu çok büyük oranda erkeklerden oluşurken, Şark Musiki bölümü eğitmenlerinin kadın ağırlıklı olduğu görülmektedir. Kadrodaki kadınlar, Dârülelhan'ın ilk döneminde kurumda öğrenci olarak bulunmuşlar; kurumun ikinci yapılanma döneminde ise eğitimci kadrosunda yer almışlardır. İlk yapılanma döneminde, ekonomik nedenlerle erkekler şubesinin daha önce kapatılması, bu dönemin Şark Musikisi bölümü kadrosunda kadın eğitimcilerin -daha uzun süre eğitim almaları dolayısıyla- kendilerine daha kolay yer bulmasına neden olduğu söylenebilir.

1923 yılında yayınlanan “Dârülelhan'1n Teşkilat ve Talimatnamesi”"nin ${ }^{40} 1$. maddesinde kurumun amacı asrın müzik gelişmelerini memlekette duyurmak, milli musikiyi bozulmaktan kurtarmak ve muhafaza etmek olarak belirtilmiştir.

Talimatnameye göre; Garp musikisi bölümünde kompozisyon, teganni, piyano, keman, alto, viyolonsel, flüt ve orkestra âlât-ı musikiyyesi: klarnet, obua sınıfları bulunmaktadır. Öğrenciler bu sınıflardan yalnızca birini seçebilmektedirler. Tüm sınıflar nazariyat-ı musikkiyye, tarih-i musiki ve orkestra/koro talimlerini derslerini ortak olarak almaktadırlar. Kompozisyon ve teganni öğrencileri zorunlu olarak piyano dersi almaktadırlar. Çalgı dersleri hocayla birebir olarak haftada bir, yarım saat işlenmektedir. Öğrenciler her ay bir heyetin önünde bir parça çalmak mecburiyetindelerdir. Program üç senelik planlanmış olup; müzik ve çalgı bilmeyen öğrenciler için hazırlık mahiyetinde sınıf-ı ihzâri sınıfı bulunmaktadır.

Şark musikisi şubesinde ise keman, kemençe, ney, tanbur, santur, ud, kanun ve teganni sınıfları bulunmaktadır. Tüm sınıflar şark musiki nazariyat ve tarihi, solfej, teganni ve usûlât-1 musikiyye derslerini almaktadır. Çalgı dersleri hocayla birebir olarak haftada bir saat işlenmektedir. Şark musikisi nazariyatı ve tarihi dersi haftada birer saat olmak üzere 30-40 kişilik öğrenci grubuyla yapılırken, solfej ve teganni ve usûlât-1 musikiyye dersleri ise yine

38 Kara, Kuruluşunun 100. Yılında Darülelhan, 67.

39 Kara, Kuruluşunun 100. Yllında Darülelhan, 67.

40 Ayr. bilgi için bk.: Volkan Celal Kaya, Dârülelhân Talimatnamesi ve Ders Müfredat Programı (İstanbul, 2016). 
haftada birer saat onar kişilik gruplar halinde işlenecektir. Bu şubede 'tecrübe devresi' dört ay olarak düzenlenmiştir.

Yönetmelikten 3 yıl sonra, 1926'da kurumun ders müfredat programı yayınlanmıştır. Bu programda, her sınıf için yıl bazında çalınacak eserler ya da metodlar belirtilmiş ve toplu derslerin içerikleri aktarılmıştır. Program incelendiğinde, Garp musikisi şubesinin özellikle keman ve piyano sınıflarının müfredatının uygulanmasının zorluğu göze çarpmaktadır. Müzik bilmeden kuruma gelen öğrencilerin eğitim alacağı keman sınıfının, tecrübe ve ihzâri devresi’nde çalınacak eserler Mazas Etüdleri no:2 ve Rode no:6 ile Viotti no:23 konçertoları olarak belirlenmiştir (Resim 2). Ancak bu eserler hem arşe teknikleri hem ileri pozisyonlar hem de çalım teknikleri olarak başlangıç aşamasına uygun olmayan eserlerdir. Günümüz konservatuvar eğitiminde bu eserler 9. ve 10. sınıf müfredatlarında bulunmakta, keman eğitimine başladıktan sonraki 5. ya da 6. yılda çalınmaktadır. ${ }^{41}$ Dârülelhan programına göre ise bu eserler 6 ay içinde çalınacaktır/çalınmalıdır. Dârülelhan eğitim vermeye başladıktan üç yıl sonra yayınlanan bu programın, -konser programlarının düzeyi göz önüne alınarak- tam olarak uygulanamadığı ve uygulanamayacağı düşünülmektedir.

Cemal Reşit Rey (1904-1985), Paris’ten Dârülelhan'ın Garp musikisi şubesinde çalışmak üzere İstanbul'a döndüğünde kurumdaki anılarını şöyle anlatmıştır: "Ben ilk kurduğum koro ile Mozart Requiem söyletmiştim öğrencilere. Tabii ki koroda çarşaflı hanımlar, fesli beyler vard1." ${ }^{42}$ Cemal Reşit Rey'in bu ifadelerinden toplumun yaşayışının ve kurumda yapılan müziğin henüz birbirine entegre olamadığını düşündüğü ve Avrupa' da eğitim almış bir kurum çalışanı olarak Rey’in bu durumu şaşkınlıkla karşıladığını anlamaktayız. Rey'in anlattığı bir başka anısı ise Türk müziği ve Batı müziğinin aynı kurumda öğretilmesinin eğitmenler arası etkileşimi göstermesi açısından dikkat çekicidir. Dârülelhan'ın kütüphanesindeki piyanoda çalışan Rey, kütüphane memuru Fazıl'ın sözlerini şaşkınlıkla karşılar:

"Fazıl bana, 'Ey Avrupalı, yeter artık bunca Avrupa müziği yazıp çaldığın. Bizim bu kadar oyun havalarımız var, türkülerimiz var. Onlar üstüne bir parça uğraşsana' dedi. Zihnimde şimşekler çaktı. Ne kadar manidar, demek ben o güne kadar Avrupa müziği yapıyordum. 'Ama elimde hiçbir malzeme yok ki' diye cevapladım Fazıl'ı. Beni yakalayıp Udi Sedat Bey’in odasına götürdü. Sedat Bey bana saatlerce, bir gün boyunca oyun havası ve türkü çalıp dinletti. Hepsini not ettim. Bir hafta sonra "Sarı Zeybek"i besteleyip Fazıl'a çaldım. $\mathrm{O}$ koca cüssesi ile beni tutup havalara kaldırdı sevincinden. Bundan sonra böylece 12 tane Anadolu şarkısı yazdım ve Paris’te bastırdım." ${ }^{43}$

Benzer şekilde Cemal Reşit Rey’in programlı müzikleri de Sedat Bey’in müziğini etkilemiştir. ${ }^{44}$ Dolayısıyla, iki şubenin eğitmenlerinin birbirlerinin bilgilerinden faydalandıkları ve üretimlerini bu bilgileri de ekleyerek şekillendirdiklerini söylemek yanlış olmayacaktır.

41 Ayr. bilgi için bk. "İstanbul Üniversitesi Devlet Konservatuvarı Lise Müfredatı", erişim 14 Mart 2021, http:// cdn.istanbul.edu.tr/FileHandler2.ashx?f=keman_636815166094546289.pdf

42 İlyasoğlu, "Melodiler Yuvası. Ne güzel İsimmiş!", 11.

43 İlyasoğlu, "Melodiler Yuvası. Ne güzel İsimmiş!", 11.

44 Evin İlyasoğlu, Cemal Reşit Rey (İstanbul: Yapı Kredi Yayınları, 1997), 108. 
Süs dergisinde yayımlanan "Dârülelhan'da Bir Ders" atmosferi samimi bir dille anlatılmaktadır. Yazının girişinde Dârülelhan’ın müdürü Musa Süreyya Bey' in kadınlara 'dedikoducu' demesine "Süreyya Efendi'ye ithaf: Dedikoducu! Bu, bizim başmuharririn umum kadınlara tevcih-i vecihi! Onun bu iltifatına (!) layık olmak için, işte, daha ilk satırda mini mini bir dedikodu ile kendisine dokundum. Bundan sonra da hiçbir fırsatı kaçırmayacağımdan emin olabilir." sözleriyle kurum müdürünün cinsiyetçi söylemine sitem edilmiştir. Dârülelhan "Burası bir mektep mi, bir cemiyet mi, yoksa bir müessese-i hayriye mi nedir? Emin olunuz ki hiçbiri değil. Ma'amafih bunlara yakın. İsterseniz mektep diyelim, hatta arzu ederseniz bir de isim koyalım: Nağmeler mektebi!” şeklinde tarif edilmiştir. Bu sözlerden kuruma dışarıdan bakan kişilerin, Dârülelhan'ı tam olarak konumlandıramadıkları anlaşılmaktadır.

Dârülelhan, bu dönemde verilen eğitimin yanı sıra konserler, derleme çalışmaları, yayın faaliyetleri ile ilk dönemden çok daha verimli bir kurum olarak faaliyet göstermiştir. Dârülelhan Mecmuası'nda aktarıldığına göre, Dârülelhan 15 günde bir Garp ve Şark şubeleri konser vermekte; bu konserler dönemin süreli yayınlarında çıkan yazılara göre büyük ilgi görmektedir (Resim 3). Her iki şubenin ortak verdiği konserlerde Şark Musikisi şubesi konserlerinin bölümlere ayrıldığı görülmektedir. Örneğin; 28 Mart 1924’te gerçekleşen konserde Şark Musiki şubesi eserleri ‘eski musiki eserleri’ ve 'yeni musiki eserleri' olmak üzere iki bölümde seslendirmiştir. Ancak eski ve yeni eserler için tarihsel bir eskilik/yenilik sınıflandırması yapılmamış; Dede Efendi (1778-1846), Zekâi Dede (1824-25/1897) gibi bestecilerin eseri ile eski musiki eserleri bölümünü yöneten İsmail Hakkı Bey’in (1866-1927) eserleri bu bölümde seslendirilmiştir. Yeni musiki eserleri bölümde ise bu bölümü yöneten Muallim Sedad'ın (1890-1947) eserleri seslendirilmiştir. 23 Ocak 1925 tarihli konserde Hüseyin Sadeddin Bey'in (1880-1955) Suzinak Peşrevi haricinde yeni musiki eserleri başlıklı bölümde sadece Sedad Bey’in eserleri çalınmıştır. Dârülelhan'ın bu dönemde verdiği konserler ilk dönemin aksine, basında genel olarak olumlu eleştiriler almıştır. ${ }^{46}$

Ancak yazılan bu yazıların yanında kadın ve erkeklerin aynı sahnede olmasını gayriahlaki bulan bir yazı da kaleme alınmıştır. 12 Aralık 1924 tarihinde Garp musikisi bölümünün öğrenci konseri ile ilgili yazılan “Aristokrasi Sınıfının Şaaşalı Eğlenceleri” başlıklı yazı bu konuda çok sert sözler içermektedir.

“İşte 'hürriyet-i nisvân' duasının karar kıldığı netice! Kadını 'esaret'den kurtarmak için senelerden beri mütemadiyen onun namına bağırıp çağıranların asıl maksatları ne olduğu artık anlaşıldı: Müslüman hanımlarının süslenerek sahnelere çıkması, sazendelik ve muganniyelik, yahut aktrislik ederek beyleri eğlendirmesi, umumi salonlarda herhangi erkeğin kollarına takılarak birlikte dans etmesi!.. (...) Bunlar hep demokrasi kisvesine bürünmüş aristokrasi hayatının şayan-1 ibret safhalarıdır."

45 Halide Nusret Zorlutuna, "Dârülelhan'da Bir Ders", Süs 27 (1923), 3-4.

46 Ayr. bilgi için bk. Kara, Kuruluşunun 100. Yllinda Darülelhan.

47 Akt. Kara, Kuruluşunun 100. Yllında Darülelhan, 81. 
Müslüman kadınların sahnede olması, demokrasi ve kadın hakları kisvesi altında aristokrasi sınıfının, kendi hayat tarzlarını halka 'mübah telakki' ettirme çabası olarak yorumlanmıştır. Bununla birlikte müziğin ve/veya müzik eğitiminin de sınıfsal bir konumda ele alınmış olması dikkat çekicidir.

Kadınların sahnede olmasıyla ilgili yayımlanan diğer bir uçtaki örnek ise Güzide Sabri Aygün'ün (1886-1946) ‘Güzide Osman’ takma adıyla Süs dergisinde yayımlanan yazısıdır.

“ 'Dârülelhan' müsameresi, itiraf ediyorum, çok samimi, çok benliğimi okşayan bir gündü... Hayat yollarının her köşesinde kendine bir çalışmak hakkı ayıran Türk kadını, bu, esasen şiir ve aşk yurdu olan bedî‘î sanatında da büyük deha ve kabiliyetini gösterdi... Şark kadını bu ruhî ve bedi'î ihtiyacı çok hissetti. Ve çok çalıştı. Sarsılmayan azmi, eksilmeyen sebatıyla her şeyde muvaffak olan Türk kadını bugün musikisinin de kahramanı oluyor. Ve onun için bugün artık millî gururumuzun, milli an'anelerimizin bayramındayız...”48

Dârülelhan'da verilen eğitim ve konserlerin dışında, 1924-26 yılları arasında yedi sayı yayımlanmış olan Dârülelhan Mecmuası adlı dergi, önce anket yoluyla daha sonra derleme gezileriyle halk ezgilerini kayıt altına alma çabaları, Dârülelhan Külliyâtı isimli klasik Türk müziği eserlerinin nota yayımları sözlü kültürden yazılı kültüre geçiş çabalarının göstergeleri olması bakımından önem taşımaktadır.

1926 yılında, dönemde süregelen, Şark ve Garp müzikleri hakkındaki tartışmalar dönemin basınında büyük yer bulmuştur. Bu tartışmalar resmi kurumlardan Türk müziği eğitiminin kaldırılması fikrine kadar uzanmıştır.

1926 yılında, Dârülelhan’da Şark musikisi şubesinin kapatılmasının ardından, Türk müziği, talimatname ile çalışma koşulları belirlenen 'Tasnif ve Tespit Heyeti'nin faaliyetleri ile sınırlandırılmıştır. Rauf Yekta Bey’in arşivinde kurumdan Türk müziği eğitiminin kaldırılması üzerine, Mustafa Kemal Atatürk'e hitaben yazılan ve alınan bu karardan bir an önce vazgeçilmesi gerekliliği vurgulayan bir mektup müsveddesine rastlanmıştır. Mektupta;

“ Türkiye Reis-i Cumhuru Gazi Mustafa Kemal Paşa Hazretleri'ne

Türk milletinin yetiştirdiği Farabi ve İbn-i Sina gibi hukema tarafindan nazari temelleri kurulan ve garbin vakıf-1 ahval musiki alimleri nezdinde ciddi bir kıymet-i aliyye ve tarihiyyesi olan Türk musikisinin Dârülelhan'da tedris edilmemesi hakkında mahza şahsi ihtiraslar sevkiyle (sabık müdür Süreyya Bey tarafından) Sanayi-i Nefise encümenince ittihaz ettirilmek istenilen verilen kararın beynelmilel musiki tarihlerinde şiddetle tenkit edilecek bir hadise olacağını kemal-i ihlas ile temin eder ve (asri prensipleri almak suretiyle her türlü tekemmülata müstaid ..... ve milli harsımızın tarihinde aleyhimize tarihi kalacak böyle bir kararın) Maarif Vekaleti'nce mevkii-i icraya konulmaması için her hususta milletimize doğru yolu gösteren büyük ve mukaddes Gazimizin atabe-i şevketine ilticaya mecburiyet gördüğümüzü arz ile beraber bu hususta şerefsadır olacak irade-i celileleriyle kuvve-i maneviyeleri kırılmış olan muallim ve talebe kullarının ihya ve tebşir buyurulmasını bilhassa istirhama mübasaret eyleriz ferman. Dârülelhan Türk Musikisi Muallimleri Namına"49 yazmaktadır.

48 Güzide Osman, "Dârülelhanda Bir Gün”, Süs 18 (1923), 6.

49 Nilgün Doğrusöz (haz.) Rauf Yekta Bey'in Musiki Antikaları (Ankara: Atatürk Kültür Merkezi Başkanlığı, 2018), 185. 
Mektup müsveddesinde dönemin Türk müziği tartışmalarına karşılık, Türk müziğinin bilimsel tarafı ve Batılı müzik alimlerince de kabul gördüğü vurgulanarak söylemsel strateji oluşturulmuş; kararın müzik tarihine eleştirilecek bir olay olarak geçeceğinin altı çizilmiştir. Bu mektubun gönderilip gönderilmediği ya da mektuba cevap alınıp alınmadığı bilinmemektedir.

Dârülelhan'da Şark musikisi şubesinin kapatılmasının ardından, kurumdaki Türk müziği faaliyetleri Türk Musikisi İcra Heyeti ve Tasnif ve Tespit Heyeti ile sınırlandırılmış ve heyetin görevi talimatname ile çerçevelenmiştir. Alaturka Musiki Tasnif ve Tesbit Heyeti Talimatnamesi'nin birinci maddesi 'Heyet üç zattan müteşekkildir.' şeklindedir. Bu üç kişi Rauf Yekta reis olmak üzere, azalar Muallim İsmail Hakkı ve Zekâizade Hafız Ahmet Efendi'dir. Talimatnamenin üçüncü maddesi "Heyetin ilk vazifesi mahfuzatı tesbit etmektir. Bu tesbit faaliyetinde dinî eserleri takdim edecektir." maddesidir. ${ }^{50}$ Özellikle dini eserlere öncelik verilmesi kapatılmış olan tekkelerde gelişen dini mûsikî eserlerinin kaybını önlemeye yönelik olduğu düşünülebilir. ${ }^{51}$ Diğer maddeler eserlerin notaya alınması, koleksiyon sahipleri ve heyetin işleyişi ile ilgilidir. Ancak bu maddelerin altında ayrıca eklenmiş “alaturka şubesinin lâğvı üzerine tesis edilecek olan Tasnif ve Tesbit Heyetine mülhak icraî kısmın mektep anasırından mürekkep olarak ve katiyyen tedris ve talim mahiyeti olmamak şartile tedrisat olmadığı günlerde Konservatuvar müessesesinde çalışabilmeleri muvafik görülmüştür" ${ }^{52}$ açıklamasıyla Türk müziği çalışmaları açık bir şekilde sınırlandırılmıştır. Bu maddeyle heyet çalışmalarını, binada eğitim olmadığı günlerde ve kesinlikle eğitim vermemek şartıyla sürdürebilecektir. Rauf Yekta Bey, Vakit'te yazdığı "Nâmık İsmail Bey’e Cevap" yazısında ve Yenises Gazetesi’nde yayınlanan “Garpçılara Şiddetli Bir Hücûm” mülakatında bu karar henüz alınmamışken, Sanayi-i Nefise Encümeni üyelerinin Türk müziği ile ilgili fikirlerine sert açıklamalarla cevapta bulunmaktadır. Kararda imzası bulunan Sanayi-i Nefise Encümeni üyelerinden İsmayıl Hakkı Baltacıŏlu'nun (1886-1978), 1934'te yayımlanan bir yazısında, bu sınırlamaya dair: "Alaturka musiki irtica musikisidir, ona müdahale etmek lazımdı" denmektedir. ${ }^{53}$

Bu şartlarda çalışmaya başlayan Tasnif ve Tespit Heyeti'nin Türk müziği ile ilgili yayın, araştırma ve Türk müziği eserlerinin tespit edilmesi konusundaki çalışmaları, Türk müziğinin bilinçli bir şekilde ilk kez kayıt altına alınması ve sistematik ilk çalışmalar olması yönüyle çok önem taşımaktadır.

Türk müziği şubesinin kapatılması ve Tasnif ve Tespit Heyeti kurulması, geleneğin süreklilik, aktarım ve canlılık özelliğini yitirdiği, gelecekle kurduğu bağın kaybolduğu hissine neden olmuştur. Türk müziği sadece geçmişe ait bir kültürel kalıntı olarak algılanıp, bu müzik türünün modernleşen toplumda hayatta kalamayıp hükmünü ve değerini yitirdiği algısına sebebiyet vermiştir. Alınan bu kararla Türk müziğinin 'tarihselleştirilmiş’ hale getirildiği söylenebilir. Rauf

50 Ergin, Türkiye Maarif Tarihi, 1588.

51 Nuri Özcan, “Darülelhan Osmanlı Devleti'nde Kurulan İlk Musiki Mektebi”, Türkiye Diyanet Vakfi Íslam Ansiklopedisi, (İstanbul: Diyanet Vakfi Yay., 1993), 520.

52 Ergin, Türkiye Maarif Tarihi, 1588.

53 Akt. Seçil Deren, "Kültürel Batılılaşma”, Modern Türkiye’de Siyasal Düşünce içinde, (İstanbul: İletişim, 2002) $3: 398$ 
Yekta Bey yazısında bu durumu 'Türk müziğini müzeye kaldırmak' olarak tanımlamaktadır. Ayas'a göre bu uygulamalar, bizzat devlet kurumları tarafından bilinçli bir siyaset çerçevesinde oluşturulmuştur. ${ }^{54} \mathrm{Bu}$ duruma rağmen Tasnif ve Tespit Heyeti'nin çalışmaları, Türk müziğinin tekkelerden ve Dârülelhan'dan kaldırıldığı dolayısıyla sözlü aktarımının sekteye uğradığı bir dönemde yazılı repertuvar oluşturarak eserlerin kaybolmamasını sağlamak adına önem taşımaktadır.

Bu süreçten sonra Dârülelhan, “22 Ocak 1927 tarihinde İstanbul Mûsiki Konservatuarı adı altında İstanbul Şehremaneti’ne bağlanmıştır." ${ }^{55}$ Cemal Reşit Rey o dönem konservatuvar isminde 1srarcı olsa da sonrasında pişmanlığını şöyle ifade etmiştir: "Düşünün Lâhinler Yuvası, Melodiler Evi. Daha güzel bir ifade tasavvur edebilir misiniz? Orada kıyametler gibi ısrar etmiştim konservatuvar konsun diye. Şimdi bundan fevkalade pişmanım”. ${ }^{56}$ Dârülelhan ismi ise; bu değişikliğinin yaşandığı zamanlarda açılan Eskişehir Dârülelhanı, Kıbrıs Darül Elhan Musiki Derneği gibi derneklerde yaklaşık sekiz-on yıl kadar daha yaşamıştır.

\section{Sonuç}

Osmanlı Devleti'nin ve Türkiye Cumhuriyeti'nin ilk konservatuarı olma hüviyeti taşıyan Dârülelhan, iki yapılandırılmasında da dönemin müzikal beğeni ve üretimini yeniden inşâsında önemli bir misyona sahiptir. Kuruluş aşamalarında verilen röportajlar ve yönetmeliklerde kurumun amaçlarını açıklayan maddeler incelendiğinde, Dârülelhan'ın müzik alanında gerçekleşmesi beklenen değişimin şekillendirici resmi kurumu olarak algılandığı açıktır. Türk müziğinin kurumsallaşma ihtiyacı doğrultusunda açılan Dârülelhan'ın, 1916 yılında talimatnamesi yayınlanan ilk döneminde, Türk müziğinin bilimsel olarak uygulamasının yapılması, eski eserleri kayıt altına almak ve canlandırmak en temel amaçlar olarak belirlenmiştir. Bu amaçlar gerçekleştirilirken de hem nota ile eğitimin yapılması hem de edvarlardan faydalanılması gerekliliği vurgulanmıştır. Kurumun temel amaçları, dönemde hâkim olan pozitivist ve rasyonel düşüncenin müzik alanına yansıması gibidir. Sözlü kültür ögesi olan meşk sistemi ile aktarımı sürdürülen Türk müziğinin aktarım geleneği, yazılı kültüre adapte edilmeye çalışılmış; araç olarak Avrupa müziğine dair bir unsur olan nota kullanılsa da bilimsel öğretide referans olarak Türk müziği teorisinin aktarımının en önemli kaynakları olan edvarlar işaret edilmiştir. Osmanlı Devleti'nde Batılılaşma süreci ile başlayan Türk müziği geleneğinin çeşitli alanlarındaki değişimin de Dârülelhan'da verilen eğitim ve sanat faaliyetleri ile kurumdan mezun olan öğrenciler aracılığıyla şekillendirilmeye çalışılması da amaçlanmaktadır. Ancak kurumun ilk döneminde maddi sıkıntılar, Dünya savaşının etkileri benzeri nedenlerle Dârülelhan planlandı̆̆ı şekilde faaliyet gösterememiştir.

1923 yılında eğitime başlanan ikinci yapılanma dönemi ise Dârülelhan'ın, Avrupa'daki muadilleri gibi 'asri' bir kurum olarak faaliyet göstermesi beklenmektedir. Nota ile eğitim, her

54 Onur Güneş Ayas, Müzik Sosyolojisi Sorunlar-Yaklaşımlar-Tartışmalar (İstanbul: Doğu Kitabevi, 2015), 295.

55 Nuri Özcan, “Darülelhan Osmanlı Devleti’nde Kurulan İlk Musiki Mektebi”, Türkiye Diyanet Vakfi İslam Ansiklopedisi. (İstanbul: Diyanet Vakfi Yay., 1993), 520.

56 İlyasoğlu, Cemal Reşit Rey, 97. 
sınıf için hazırlanan standart programlar, çalgı eğitiminin belirlenen metotlarla planlanması bu 'asri' olma hedefinin göstergeleridir. Gerek sanatsal etkinliklerle gerekse kurumda yapılan çalışmalar ile bu dönem ilk dönemden daha verimlidir. Bu çalışmalar ile yapılması planlanan faaliyetlerin daha çok örtüştüğü görülmektedir. Yapılan konserlerden, nota kullanımından, yayın faaliyetlerinden anlaşıldığı üzere Türk müziğinin aktarım ve icra geleneğinde değişimler gözlemlendiği gibi; Türk müziği ile ilgili ilk kez bilinçli şekilde -Türk müziğinin kayıt altına alınması ve alanda sistemli ilk çalışmaların gerçekleştirilmesiyle- bir literatür oluşturma amacı taşındığı da anlaşılmaktadır.

Türk müziği alanında, 1916 ve 1926 yılları arasında, üstlendiği misyonların gerçekleştirilebilmesi için kısa sayılabilecek bir sürede ve iki farklı yapılanma ile faaliyet gösteren Dârülelhan'da; dönem şartları itibariyle kesintilerle eğitim verilse de özellikle yazılı kültüre geçiş için önemli çalışmalar yapılmış ve ve 'modern' bir anlayış ile literatür oluşturma, eser kayıt altına alma, notayla eğitime geçiş, Türk müziği ile ilgili yayın yapma hususlarında gelişmeler sağlanmıştır.

Dönemin müzik çevrelerine baktığımızda Dârülelhan'da gerçekleştirilmeye çalışılan yeniliklerin bazılarının kabul edildiği, bazılarının ise yadırgandığı görülmektedir. Müziğin aktarımında nota kullanılarak eğitimin yapılması, yazılı kültüre geçiş çabaları dönemin modernleşme etkisi ile kabul görmüş; bunun ötesinde ülkenin içinde bulunduğu şartlar nedeniyle gerçekleştirilemeyen hedefler eleştirilerin doğmasına neden olmuştur. Ancak kadınların sahnede olması toplumsal cinsiyet normları gereğince hedef alınmışken; Batılı anlamda orkestra yönetimi, -dügâh perdesinin tıpkı Batı müziğinde olduğu gibi $440 \mathrm{~Hz}$ frekansa akort edildiği- mansur akordun kabulü gibi doğrudan Batı müziğinden adapte edilen normlar Türk müziğine uygun bulunmadığı gerekçesi ile kabul görmemiş ve eleştirilmiştir.

Osmanlı Devleti'nde 18. yüzyılın başlarından itibaren askeri ve toplumsal yaşamda gözlemlenen değişmelerin, müziğin kültürel üretim sahasındaki yansımalarının Dârülelhan'da verilen eğitim ile şekillendirilmeye çalışıldığı görülmektedir. Dârülelhan'da verilecek eğitimle yetişen öğrenciler hem eskinin ve o günün müziğini, teorisini bilip aktaran hem de bunları dönüştürüren, dönemin ruhuna ve gerekliliğine uyarlayan aktörler olarak tasavvur edilmiştir. Kurumdaki eğitim için yönetmeliklerde sıklıkla üzerinde durulan nota ile eğitim sözlü kültürle aktarımı sürdürülen Türk müziğinin aktarım geleneğinin dönemin gerekliliğine uyarlanmasının sonucu olarak değerlendirilebilir. Dârülelhan'da yapılan eski eserlerin kayıt altına alınması, derleme çalışmaları, çıkarılan dergiler de bu dönüşümün izlerini taşımaktadır. Yönetmeliklerde geçen, edvarlardan faydalanılarak oluşturulacak bilimsel bir nazariyat anlatımı vurgusu ise Türk müziğinin nazariyat geleneğinin dönemin pozitivist anlayışı ile şekillendirilmek istendiğinin göstergesidir. Tüm bunların yanı sıra Dârülelhan'a, değişen toplumsal yapı içinde Türk müziğinin 'yeniden canlandırılması' ve ‘bozulmaktan korunması' amaçları yüklenmişken; aynı zamanda toplumun müzikal beğenisini şekillendirmek konusunda da önemli bir önemli bir misyon verilmiştir. 
Hakem Değerlendirmesi: Dış bağımsız.

Çıkar Çatışması: Yazarlar çıkar çatışması bildirmemiştir.

Finansal Destek: Yazarlar bu çalıșma için finansal destek almadığını beyan etmiștir.

Peer-review: Externally peer-reviewed.

Conflict of Interest: The authors have no conflict of interest to declare.

Grant Support: The authors declared that this study has received no financial support.

\section{Kaynaklar/References}

“Dârülelhan Müsameresi”. Servet-i Fünun, 12 Eylül 1918.

“Dârülelhan'ın İkinci Konseri”. Vakit, 12 Eylül 1918.

“İstanbul Üniversitesi Devlet Konservatuvarı Lise Müfredatı”. Erişim 14 Mart 2021. http://cdn.istanbul.edu. tr/FileHandler2.ashx?f=keman_636815166094546289.pdf

“Maarif Vekilimiz Demeçte Bulundu/Felsefe Terimleri Komisyonu Çalışmalarına Son Verdi”. Ulus, 14 Mart 1942. Ayas, Onur Güneş. Müzik Sosyolojisi Sorunlar-Yaklaşımlar-Tartışmalar. İstanbul: Doğu Kitabevi, 2015.

Aydın, M. Beste. Âlem-i Mûsikî (Çevriyazım ve inceleme). Yüksek Lisans Tezi, Ege Üniversitesi, 2004.

Başbakanlık Osmanlı Arşivi (BOA). BEO (Bab-1 Ali Evrak Odası) 4723/354161-1, 04-03-1341 (25 Ekim 1922).

Başbakanlık Osmanlı Arşivi (BOA). BEO (Bab-1 Ali Evrak Odası) 4723/354161-2, 04-03-1341 (25 Ekim 1922).

Başbakanlık Osmanlı Arşivi (BOA). Dahiliye (DH) EUM.AYŞ 58/123, 30-05-1340 (29 Ocak 1922).

Cevizci, Ahmet. Felsefe Sözlüğ̈̈. İstanbul: Paradigma Yayıncılık, 2005.

Dârülelhan Mecmuası. 1: 45. İstanbul: Evkaf-1 İslamiye Matbaası, 1924.

Deren, Seçil. “Kültürel Batıl1laşma”, Modern Türkiye’de Siyasal Düşünce. 3. cilt. İstanbul: İletişim, 2002.

Doğrusöz, Nilgün ve Ali Ergur. "Çatışmalar ve Dönüşümler Çağında Bir Bileşimci: Ali Rifat Çağatay”, Musikinin Asrî Prensi Ali Rifat Çağatay içinde, 19-90. İstanbul: Gece Kitaplığı, 2017.

Doğrusöz, Nilgün. "Hüseyin Sadeddin Arel'in Kaleminden Musiki Terimleri Meselesi”, 2017 Arel Sempozyumu Bildirileri içinde, 193-211. İstanbul: Türkiyat Araştırmaları Enstitüsü, 2018.

Doğrusöz, Nilgün (Hazırlayan). Rauf Yekta Bey’in Musiki Antikaları. Ankara: Atatürk Kültür Merkezi Başkanlığ1, 2018.

Durkheim, Émile. "İlm-i Terbiye ve İçtimaiyat”, İstanbul Üniversitesi Sosyoloji Dergisi 1/5 (2014): $207-224$.

Ergin, Osman Nuri. Türkiye Maarif Tarihi. İstanbul: Osmanbey Matbaası, 1977.

Ergur, Ali ve Yiğit Aydın. "Patterns of Modernization in Turkish Music As Indicators of Changing Society", Musicae Scientiae Özel Sayl (2005-2006): 89-105.

Ergur, Ali. “Türkiye’de Müziğin Modernleşme Süreci: Tampere Düzene Geçişin Yerel ve Evrensel Boyutları”, Müzikli Aklın Defteri içinde, 169-182. İstanbul: Pan Yayıncılık, 2009.

Fichter, Joseph. Sosyoloji Nedir?. Çeviren Nilgün Çelebi. Konya: Selçuk Üniversitesi Fen Edebiyat Fakültesi Yayınlar1.

Frolov, Ivan. Felsefe Sözlüğü. Çeviren Aziz Çalışlar. İstanbul: Cem Yayınevi, 1991.

Hobsbawm, Eric ve Terence Ranger. Geleneğin İcadı. Çeviren Mehmet Murat Şahin. İstanbul: Agora Kitaplı̆̆ 1 , 2006. 
İlyasoğlu, Evin. “Melodiler Yuvası. Ne güzel İsimmiş!”. Cumhuriyet, 25 Kasım 1992.

İlyasoğlu, Evin. Cemal Reşit Rey. İstanbul: Yapı Kredi Yayınları, 1997.

Kara, Ahmet. Kuruluşunun 100. Yılında Darülelhan. İstanbul: İstanbul Büyükşehir Belediyesi, 2018.

Karadeniz, S1tk1. "Gelenek Üzerine Bir Okuma Denemesi”, Milel ve Nihal Dergisi 4/2 (2007): 29-47.

Kaya, Volkan Celal. Dârülelhân Talimatnamesi ve Ders Müfredat Programı. İstanbul, 2016.

Koca, Emine. “18. ve 19. Yüzyıl Osmanlı Erkek Modası”, Türk-İslâm Medeniyeti Akademik Araştırmalar Dergisi (2009): 63-81.

Kolukırık, Kubilay. “Osmanlı Devleti’nde İlk Resmî Konservatuvar Olan Dârülelhan'da Derleme ve Yayım Faaliyetleri”, Selçuk Üniversitesi Türkiyat Araştırmaları Dergisi 35 (2014): 479-498.

Kolukırık, Kubilay. Türk Müzik Tarihinde Dârü'l-Elhan ve Dârü'l-Elhan Mecmuası. Ankara: Barış Kitap, 2015. Konservatoryum, 5(1). 2018.

Mumcu, Ahmet. "Divan-1 Hümayun". Türkiye Diyanet Vakfı İslam Ansiklopedisi. 9:431. İstanbul: TDV Yayınları, 2000.

Öncel, Mehmet. Rauf Yektâ Bey'in Âti, Yeni Mecmûa, Resimli Kitap ve Şehbâl Adlı Mecmûalarda Mûsikî ile İlgili Makalelerinin Incelenmesi. Yüksek Lisans Tezi, Marmara Üniversitesi, 2010.

Osman, Güzide. "Dârülelhanda Bir Gün”, Süs 18 (1923): 6.

Özbudun, Sibel. "Gelenek”, Antropoloji Sözlüğ̈̈. Hazırlayan Kudret Emiroğlu ve Suavi Aydın. Ankara: Bilim ve Sanat Yayınları, 2003.

Özcan, Nuri "Dârülelhan Osmanlı Devleti’nde Kurulan İlk Mûsikî Mektebi”, Türkiye Diyanet Vakfi İslâm Ansiklopedisi. (İstanbul: Diyanet Vakfi Yay., 1993).

Özden, Erhan. Osmanlı Devleti'nin Konservatuvarı Dârülelhan (Arşiv Belgeleriyle). Ankara: Atatürk Kültür Merkezi Başkanlığı, 2019.

Özsan, Gül. "Kültür ve Gelenek”, Kültür Sosyolojisi içinde, 84-103. Eskişehir: Anadolu Üniversitesi Basımevi, 2015.

Öztürk, Okan Murat. "Dârû'l-elhan” İsmindeki Sır: "Jeune” Ütopyacılığa Dair Bir Sembol”, Kuruluşunun Yüzüncü Yllında Dârü'l-Elhân'a Armağan içinde, 235-289. Hazırlayan-Editör Gülçin Yahya Kaçar. Ankara: Atatürk Kültür Merkezi Başkanlığı, 2018.

Paçacı, Gönül. "Cumhuriyet'in Sesli Serüveni”, Cumhuriyetin Sesleri içinde, 10-29. İstanbul: Tarih Vakfi Yayınları, 1999.

Sevengil, Refik Ahmet. Türk Tiyatrosu Tarihi. İstanbul: Alfa Yayınları, 2014.

Sevengil, Refik Ahmet. Yakın Çağlarda Türk Tiyatrosu. İstanbul: Kanaat Kütüphanesi, 1934.

Shils, Edward. Tradition. Chicago: The University of Chicago Press, 1981.

Toker, Hikmet ve Erhan Özden. "Osmanlı Devletinde Müzik Eğitimi Veren Önemli Kurumlar”, Rast Müzikoloji Dergisi 1/2 (2013): 107-128.

Vural, Mehmet. "Gelenek ve Dinlerin Așkın Birliği”, Doğu Batı 25 (2003-2004): 161-175.

Yahya Kaçar, Gülçin (Hazırlayan). Kuruluşunun Yüzüncü Yllında Dârü 'l-Elhân'a Armağan. Ankara: Atatürk Kültür Merkezi Başkanlığı, 2018.

Williams, Raymond. Anahtar Sözcükler. Çeviren Savaş Kılıç. İstanbul: Sena Ofset, 2012.

Zorlutuna, Halide Nusret. "Dârülelhan'da Bir Ders", Süs 27 (1923): 3-4. 


\section{Şekil, Resim, Tablo ve Grafikler / Figures, Tables and Graphics}

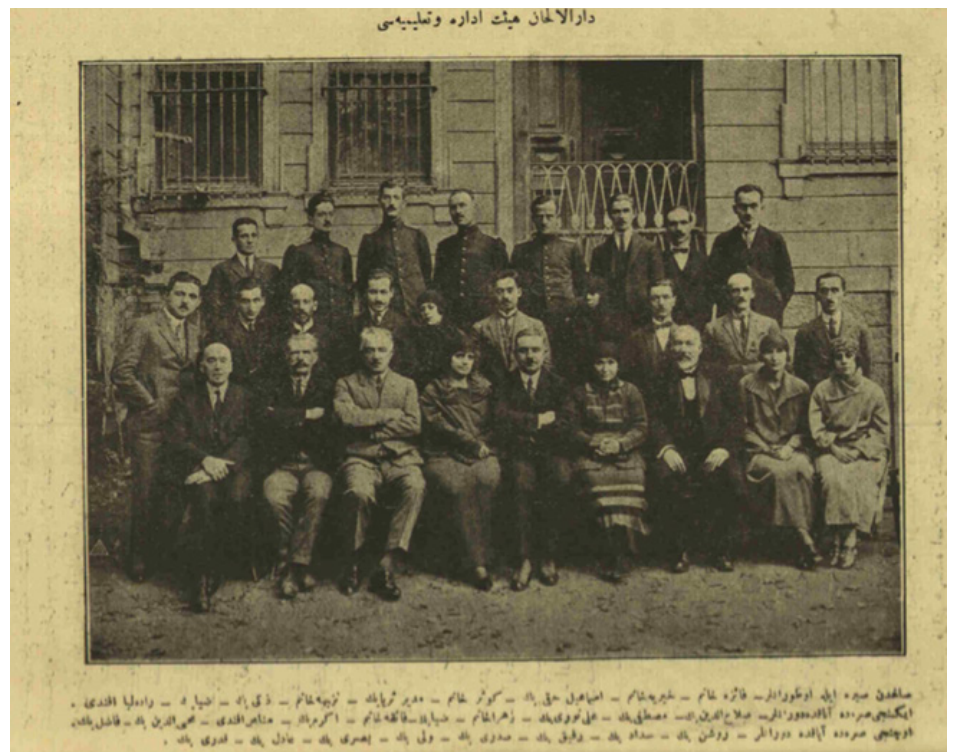

Resim 1: Dârülelhan Heyet-i İdare ve Talimmiyesi ${ }^{57}$

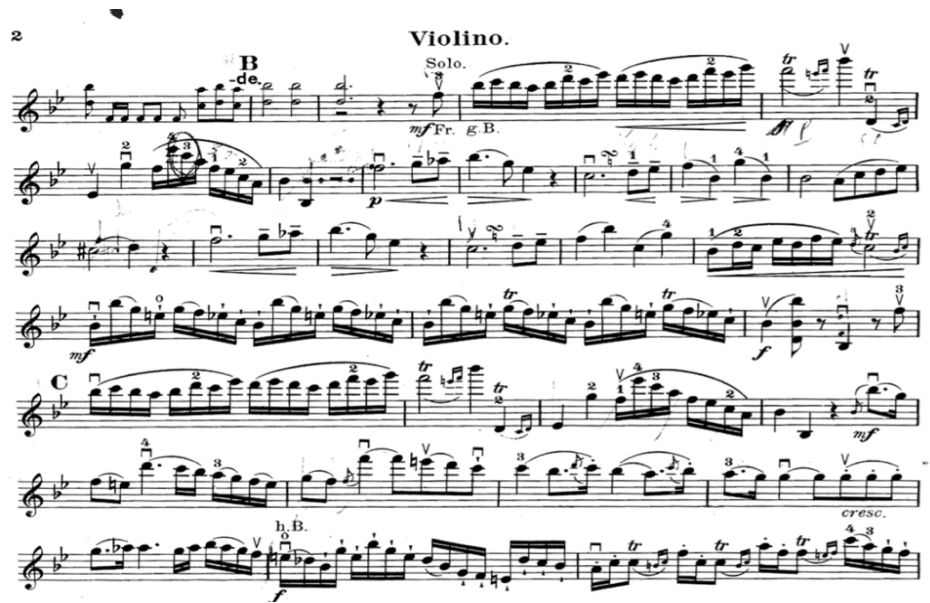

Resim 2: Tecrübe ve ihzâri devresinde çalınması beklenen Rode Konçerto no:6'dan kesit

57 Dârülelhan Mecmuası, 1: 45. Sağdan sıra ile oturanlar: Faize Hanım, Hayriye Hanım, İsmail Hakkı Bey, Kevser Hanım, Müdür Süreyya Bey, Nezihe Hanım, Zeki Bey, Ziya Bey, Radelya Efendi.

İkinci sırada ayakta duranlar: Selahaddin Bey, Mustafa Bey, Ali Nuri Bey, Zehra Hanım, Ziya Bey, Faika Hanım, Ekrem Bey, Manas Efendi, Muhiddin Bey, Fazil Bey.

Üçüncü sırada ayakta duranlar: Ruşen Bey, Sedad Bey, Refik Bey, Sadri Bey, Veli Bey, Basri Bey, Adil Bey, Kadri Bey. 


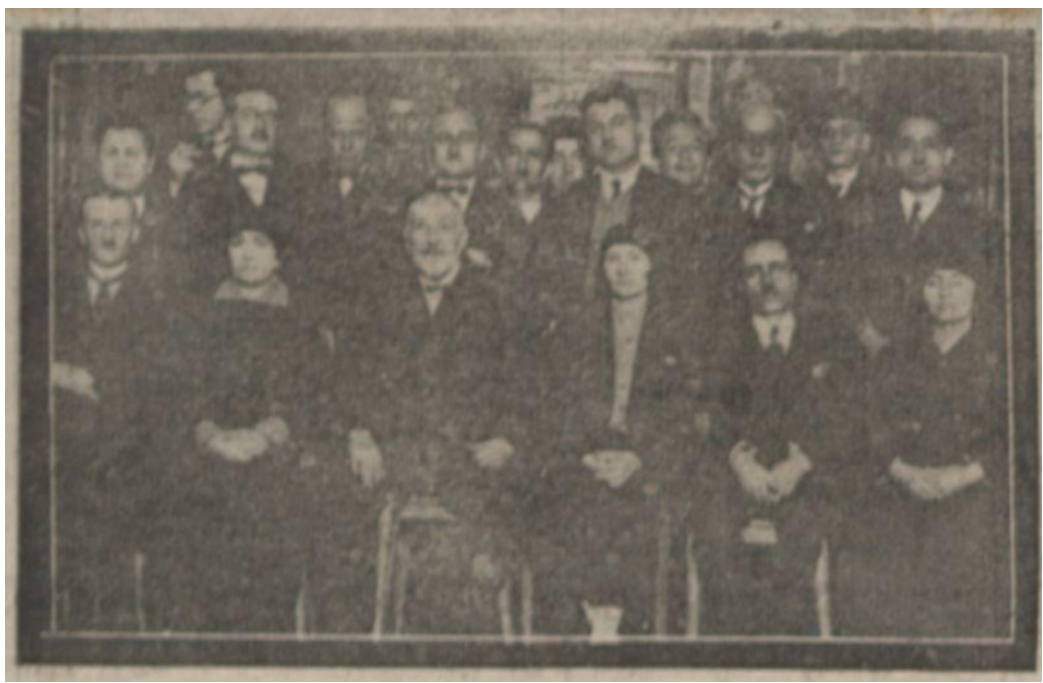

Resim 3: Vakit Gazetesi'nde yayımlanan Dârülelhan Konserleri ile ilgili yazıda kullanılan görsel

Tablo 1: Kronoloji

\begin{tabular}{|c|c|c|c|}
\hline & Dârülelhan Kronolojisi & Siyasi Olaylar & Külttürel Olaylar \\
\hline & & & $\begin{array}{l}\text { 1911- Milli Edebiyat } \\
\text { Akımı (1911-1923) }\end{array}$ \\
\hline 1914 & $\begin{array}{l}\text { Dârülbedayi bölüm kurulu } \\
\text { toplantılarının başlaması ( } 22 \\
\text { Temmuz) Dârülbedayi'nin kuruluşu } \\
\text { (27 Ekim) Abdülkadir Töre'nin } \\
\text { Maârif-i Umûmiyye Nezâreti'ne } \\
\text { lahiya vermesi }\end{array}$ & $\begin{array}{l}\text { 5. Meclis-i Mebusan’ın açılışı (14 } \\
\text { Mayıs) Kapitülasyonların kaldırılması } \\
\text { (1 Ekim) I. Osmanlı Devleti ile } \\
\text { Almanya arasında ittifak antlaşması } \\
\text { (2Ağustos) I. Dünya Savaşı'nın } \\
\text { başlaması (4 Ağustos) Osmanlı } \\
\text { Devleti’nin İtilaf Devletleri’ne savaş } \\
\text { ilanı (11 Kasım) }\end{array}$ & $\begin{array}{l}\text { İnas (Kılar) Sanayi-i } \\
\text { Nefise Mektebi’nin } \\
\text { kurulması }\end{array}$ \\
\hline 1915 & $\begin{array}{l}\text { Dârülbedayi’de Şark müziği } \\
\text { şubesinin eğitime devam etmesinin } \\
\text { kararlaştırılması }\end{array}$ & I. Dünya Savaşı & $\begin{array}{l}\text { Mekteb-i Tıbbiye'nin } \\
\text { Darülfünun'a } \\
\text { bağlanması. }\end{array}$ \\
\hline 1916 & $\begin{array}{l}\text { Dârülbedayi’nin ilk temsili (20 } \\
\text { Ocak) Dârülbedayi’nin Şark } \\
\text { müziği şubesinin kapatılması } \\
\text { (14 Mart) Maârif Nazırı Ahmet } \\
\text { Şükrü Bey'in gönderdiği Türk } \\
\text { müziği alanında bir okul açılması } \\
\text { ile ilgili tezkire (15 Haziran) İlk } \\
\text { toplantı ( } 25 \text { Haziran) Dârülelhan’ın } \\
\text { açılışı ile ilgili ilk belge-Talimat } \\
\text { ve Programın bakanlar kuruluna } \\
\text { sunulması (7 Aralık) }\end{array}$ & I. Dünya Savaşı & $\begin{array}{l}\text { Dârü’t Talim-i Musikî } \\
\text { Mektebi'nin açılması. }\end{array}$ \\
\hline
\end{tabular}




\begin{tabular}{|c|c|c|c|}
\hline 1917 & $\begin{array}{l}\text { Dârülelhan'ın açılması ile ilgili } \\
\text { irade-i senniye [padişah emri] } \\
\text { (1 Ocak) Takvim-i Vekayi'de } \\
\text { Dârülelhan Talimatnamesi ve } \\
\text { Programının yayınlanması (15 } \\
\text { Ocak) }\end{array}$ & I. Dünya Savaş1 & $\begin{array}{l}\text { Beş Hececiler'in } \\
\text { eserlerinin } \\
\text { yaygınlaşmasının } \\
\text { başlangıcı }\end{array}$ \\
\hline 1918 & $\begin{array}{l}\text { Dârülelhan'ın iç tüzüğ̈̈nün } \\
\text { yayınlanması (28 Şubat/Nisan) } \\
\text { Rauf Yekta'nın Dârülelhan'da } \\
\text { Musiki Islahatı başlıklı yazının } \\
\text { yayımlanması (12 Mart) Meclis-i } \\
\text { Ayan tutanaklarında kayıtlı } \\
\text { Dârülelhan ve Musiki Encümeninin } \\
\text { görevlerinde dair konuşma. (19 } \\
\text { Mart) Zekaizade Ahmed (Irsoy) } \\
\text { Bey’in istifası. Dârülelhan'ın ilk } \\
\text { konseri (29 Mayıs) } \\
\text { İkinci konser (11 Eylül) Santurî } \\
\text { Ziya Bey'in sağlık sorunları } \\
\text { nedeniyle ihracı (Kasım) }\end{array}$ & $\begin{array}{l}\text { I. Dünya Savaşı Osmanlı Devleti'nin } \\
\text { parçalanması Sultan Vahdettin'in } \\
\text { tahta geçişi (3 Temmuz) Mondros } \\
\text { Mütakeresi (30 Ekim) İstanbul'un } \\
\text { İşgali (13 Kasım) }\end{array}$ & \\
\hline 1919 & $\begin{array}{l}\text { Erkekler şubesinin binasının } \\
\text { sahibinin ödenmeyen kira } \\
\text { nedeniyle mahkemeye başvurması. } \\
\text { Mahkemenin erkekler şubesinin } \\
\text { binanın tahliyesine karar vermesi } \\
\text { (14 Temmuz) Âlem-î Mûsikî } \\
\text { dergisinde yayımlanan Dârü'l- } \\
\text { elhân'ın Lağvı başlıklı yazı (1 } \\
\text { Ekim) }\end{array}$ & $\begin{array}{l}\text { Mustafa Kemal'in Anadolu'ya } \\
\text { gönderilmesi (Mayıs) Kurtuluş Savaşı } \\
\text { başlangıcı }\end{array}$ & $\begin{array}{l}\text { Muallim İsmail Hakk1 } \\
\text { Bey'in Usulat, Solfej, } \\
\text { Makamat ve İlaveli } \\
\text { Nota Dersleri eserinin } \\
\text { yayımlanması }\end{array}$ \\
\hline 1920 & & $\begin{array}{l}\text { Kurtuluş Savaşı Son Osmanlı Meclis-i } \\
\text { Mebusan'ın dağılması Misak-1 Milli } \\
\text { (28 Ocak) İstanbul'ın 2. kez işgali } \\
\text { (16 Mart) T.B.M.M.'nin açılması (23 } \\
\text { Nisan) Sevr Antlaşması (10 Ağustos) }\end{array}$ & \\
\hline 1921 & $\begin{array}{l}\text { Dârülelhan Konseri ( } 20 \text { Mart) } \\
\text { Zükûr kısmındaki bazı hocaların } \\
\text { kurum içi farklı görevlere } \\
\text { getirildiği bazılarınında maaşlarının } \\
\text { kesildiğini gösteren belge. (2 } \\
\text { Ağustos) }\end{array}$ & Kurtuluş Savaşı & \\
\hline 1922 & $\begin{array}{l}\text { Dârülelhan Konseri (15 Mayıs) } \\
\text { Şehzadebaşı'nda verilen konser } \\
\text { nedeniyle İstanbul Valisi tarafından } \\
\text { Dahiliye Nezareti'ne gönderilen } \\
\text { yazı (Eylül) Dârülelhan'ın } \\
\text { kapatılması ile ilgili yazışma. } \\
\text { Alanındaki tek eğitim kurumu } \\
\text { olması nedeniyle kurumun } \\
\text { kapatılmama kararı. (Ekim) }\end{array}$ & $\begin{array}{l}\text { Kurtuluş Savaşı bitişi Saltanatın } \\
\text { Kaldırılışı (1 Kasım) }\end{array}$ & $\begin{array}{l}\text { Encyclopedie de } \\
\text { la Musique et } \\
\text { Dictionnaire du } \\
\text { Conservatoire'da } \\
\text { Rauf Yekta'nın } \\
\text { kaleme aldığı 'Türk } \\
\text { Müziği' maddesinin } \\
\text { yayımlanması }\end{array}$ \\
\hline
\end{tabular}




\begin{tabular}{|l|l|l|l|}
\hline 1923 & $\begin{array}{l}\text { Dârülelhan'ın Maarif Vekaleti'nden } \\
\text { ayrilıp, İstanbul Valiliğine } \\
\text { bağlanması. İstanbul'da Büyük Bir } \\
\text { Konservatuvar Açıllyor başlıklı } \\
\text { yazı. (31 Temmuz) Dârülelhan'ın } \\
\text { resmi olarak tekrar açılması. (14 } \\
\text { Eylül) }\end{array}$ & $\begin{array}{l}\text { Lozan Antlaşması (24 Temmuz) } \\
\text { Son İtilaf birliğinin İstanbul'dan } \\
\text { ayrılması (4 Ekim) İstanbul'un } \\
\text { işgalden kurtuluşu (6 Ekim) Türkiye } \\
\text { Cumhuriyeti'nin kuruluşu (29 Ekim) }\end{array}$ & $\begin{array}{l}\text { Ziya Gökalp'in } \\
\text { Türkçülügün Esasları } \\
\text { kitabının yayınlanması. }\end{array}$ \\
\hline 1924 & $\begin{array}{l}\text { Dârülelhan Mecmuası'nın } \\
\text { yayımlanmaya başlaması. (Şubat) }\end{array}$ & $\begin{array}{l}\text { Hilafetin kaldırılması (3 Mart) Yeni } \\
\text { anayasının kabulu (20 Nisan) }\end{array}$ & $\begin{array}{l}\text { Rauf Yekta'nın } \\
\text { Gavsiyye eserini } \\
\text { yayımlaması. Tevhid-i } \\
\text { Tedrisat Kanunun } \\
\text { çıartılması. (3 Mart) }\end{array}$ \\
\hline 1925 & $\begin{array}{l}\text { Dârülelhan İç Tüzük'ünün } \\
\text { yayımlanması. Dârülelhan } \\
\text { Külliyatı'nın basılmaya başlanması. } \\
\text { Derleme gezileri. Türk Müziği } \\
\text { eğitiminin kaldırılması. (9 Aralı) } \\
\text { Tasnif ve Tespit Heyeti'nin } \\
\text { kurulması. }\end{array}$ & $\begin{array}{l}\text { Mekke ve Zaviyeler kapatıldd. (2 Eylül) } \\
\text { Miladi takvime geçiş için kanun } \\
\text { hazırlanması }\end{array}$ & \\
\hline
\end{tabular}




\section{EKLER}

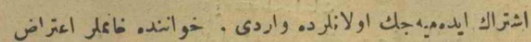

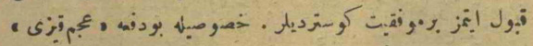

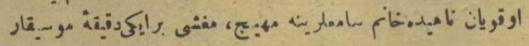

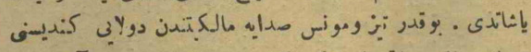

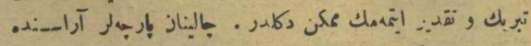

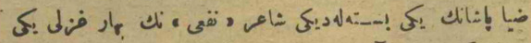

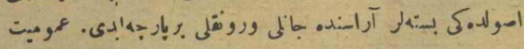

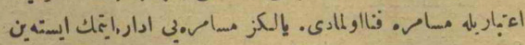

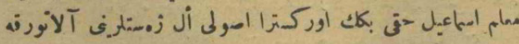

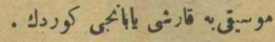

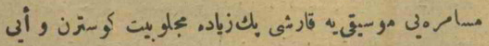

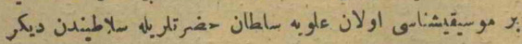

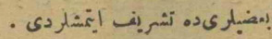

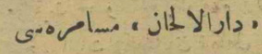

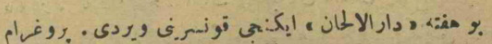

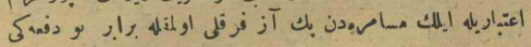

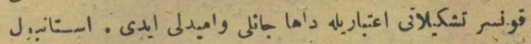

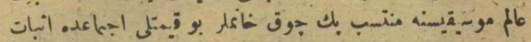

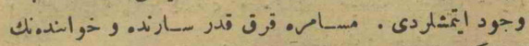

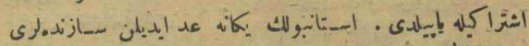

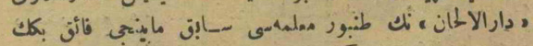

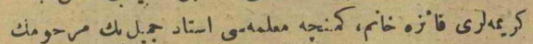

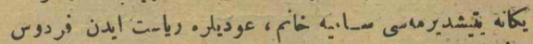

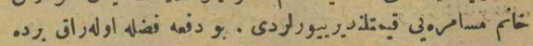

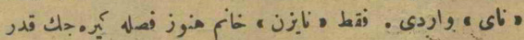

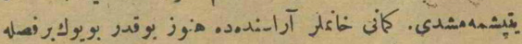

EK-1: “Dârülelhan Müsameresi” yazısı Servet-i Fünun, 12 Eylül 1918

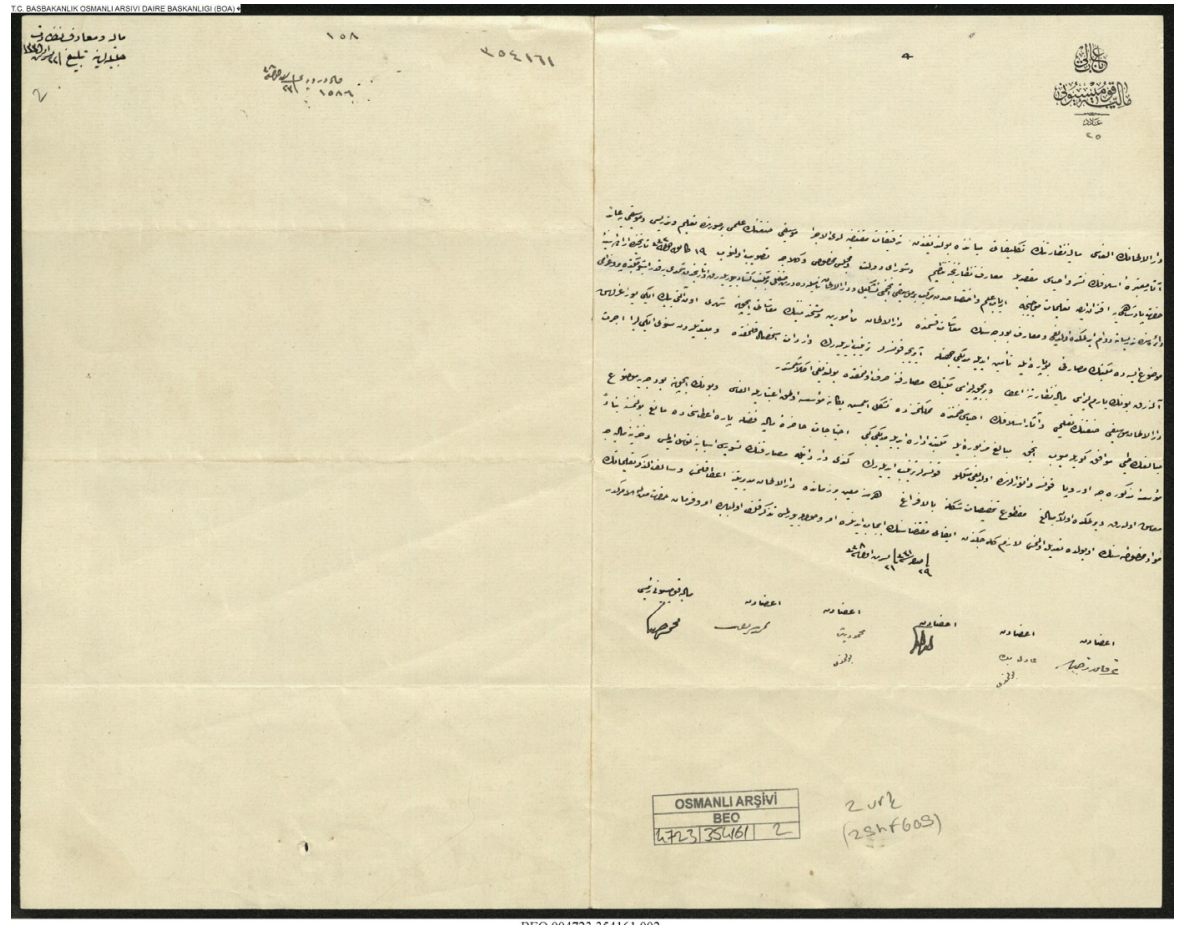

EK-2: Dârülelhan'ın ilgası ile ilgili belge 


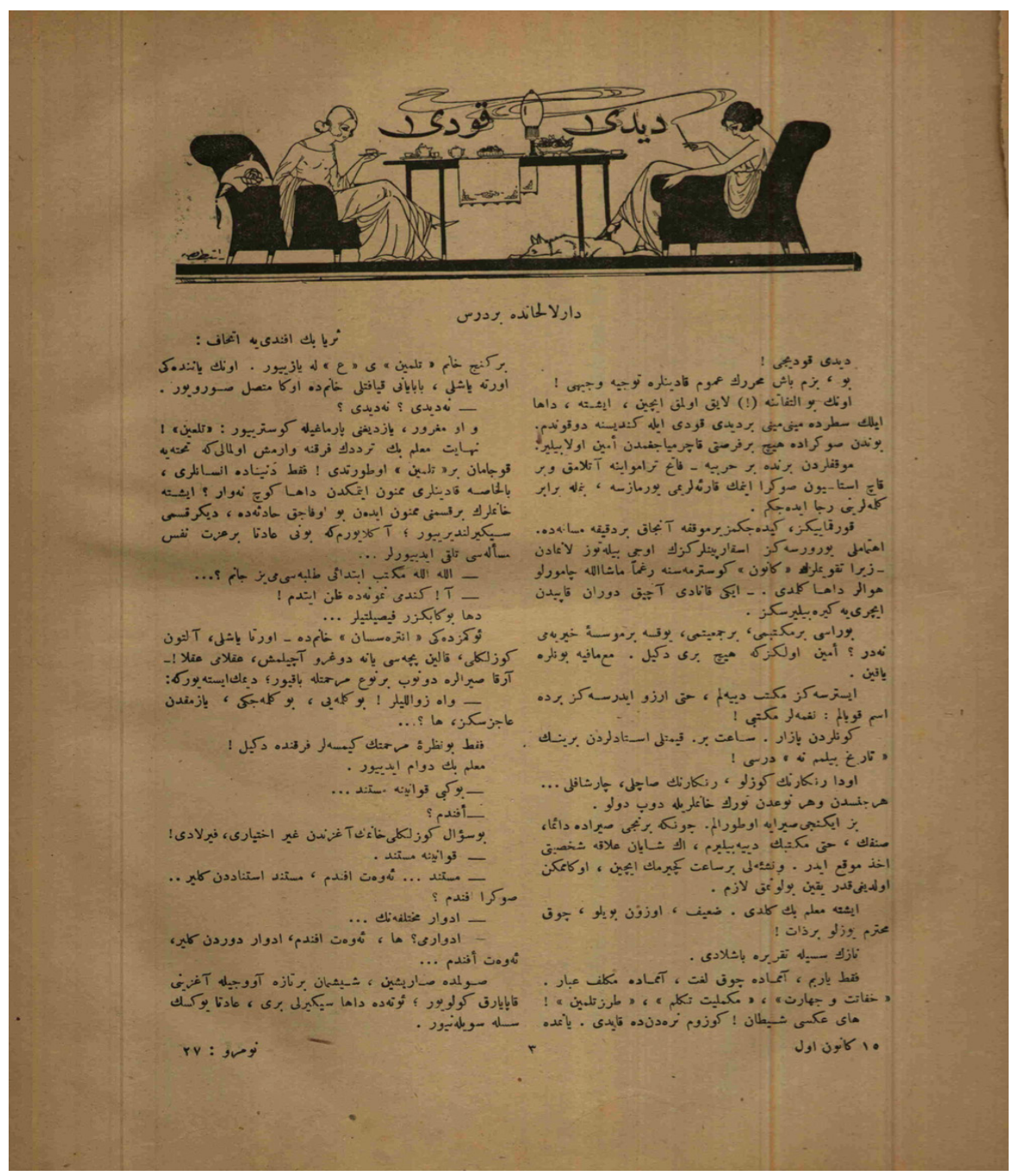

EK-3: "Dârülelhan'da Bir Ders" başlıklı yazı 
